\title{
Condorcet's Social Mathematic, A Few Tables
}

\author{
Pierre Crépel, Université Lyon I (CNRS), Lyon, France \\ Jean-Nicolas Rieucau, Université Paris I (PHARE-CNRS), Paris, \\ France, Université Paris VIII (LED), Saint-Denis, France
}

\begin{abstract}
"We might even be nearing the time when, in several branches of political sciences, everything that reason alone can do will be at an end, and the application of calculus will be the sole means of progressing further."

Rapport et projet de décret sur l'organisation générale de l'instruction publique [1792-1793]
\end{abstract}

A new impetus was given to Condorcet (1743-1794) scholarship in the second half of the last century with pioneering works by K. J. Arrow [1951, 1963], G. T. Guilbaud [1952] and D. Black [1958]. Earlier, only two major studies by L. Cahen [1904] and H. Delsaux [1931] had been available. The Essai sur l'application de l'analyse à la probabilité des décisions rendues à la pluralité des voix [1785] came to be considered retrospectively as a seminal work for social choice theory, as a broader interest in Condorcet's project of a mathematical social science arose. A study by G. G. Granger [1956] was followed, a few decades later, by books by R. Rashed [1974] and K. M. Baker [1975], which are still milestones of Condorcet scholarship. The bicentenary celebrations of the French Revolution and of Condorcet's death (1994) led to a revival of scholarly interest and a wealth of new research on that topic was published in the 1980s-1990s. ${ }^{1}$ Therefore, the Tableau général de la science qui a pour objet l'application du calcul aux sciences politiques et morales [1793], ${ }^{2}$ in which the project of the Social Mathematic is presented, has become one of his most famous writings, likewise the Essai sur l'application de l'analyse, the Vie de M. Turgot [1786] and Esquisse d'un Tableau historique des progrès de l'esprit humain [1793-1794]. However, no research has been done, as far as we know, on the specific circumstances in which that text was written. Indeed, the Tableau, which was probably unfinished, was written in haste by Condorcet in a tense political climate [Part One]. What's more, blemishes in the original draft remained uncorrected, and alterations were introduced by the editors. The first edition of the Tableau, in June-July 1793 already departed from the manuscript in some

\footnotetext{
${ }^{1}$ In the last 20 years, over 30 studies have been directly or indirectly devoted to Condorcet's Social Mathematic. A selected bibliography can be found in J. P. Lagrave \& M. Breguet [1993, p. 322-325], with more references in B. Bru \& P. Crépel [1994] and E. Brian [1997].

2 The French quotes given in the footnotes are taken from the original edition, which is the least faulty, though the spelling has been modernised. Page references refer to that edition. The English translation, by E. de Champs, is based on I. McLean and F. Hewitt [1994], though alterations have been made punctually. Titles of Condorcet's works have been left in French throughout.

Hereafter, the phrase "political and moral sciences" will be used as a synonym for "social sciences". Before the Revolution, Condorcet used indifferently the phrases "moral sciences", "political sciences", "political and moral sciences", "moral and political sciences". During the Revolution, there were more occurrences of each of those expressions, but the phrase "social science(s)" was also sometimes used. As K. M. Baker [1964] has shown, the Société de 1789, of which Condorcet was one of the most active members, contributed to promote the use of the expression "social science(s)". In his Tableau général [p. 106], Condorcet explained that he preferred the adjective "social to those of moral and political", whose "meaning" was "more restricted and less precise". However, he did not stop using those words, in the title itself [p. 105] and in the text [p. 105, 108, 184]. These slight variations subsist in later writings.
} 
Condorcet's Social Mathematic - A Few Tables

places. Condorcet, who went into hiding on July $8^{3}$ did not have the time to check the prints. Faulty early editions were taken as models for all subsequent ones, ${ }^{4}$ without any attention being paid to the mistakes they contained, and alterations were often introduced. Mistakes are mostly present in the synoptic description of the Tableau général, on which the entire demonstration hinges. Its original division under two headings - "objects" and "method"- needs to be restored, as well as their connection with the "preliminary theories" of the Social Mathematic. It then becomes possible to understand how Condorcet conceived the various fields of investigation of the Social Mathematic and in what respects it differs from traditional political arithmetic [Part Two]. In a manuscript published here for the first time, ${ }^{5}$ the Tableau général is presented under two equally important headings, allowing a comprehensive understanding of Condorcet's project. Presenting the Social Mathematic according to its "objects" and its "method" also highlights the place it occupies within the table of human knowledge. This analysis is corroborated by all of Condorcet's printed works as well as by an unpublished manuscript. ${ }^{6}$ [Part Three]

\section{THE TABLEAU GÉNÉRAL, A TEXT WRITTEN CURSORILY}

The dates given for the composition of Condorcet's Tableau général in most editions are often faulty. In the "complete" edition of his works put together by his widow, Sophie de Grouchy, in 1804, none are given. Fayolle, in his 1805 edition, presents it as an "introduction"7 to the Elémens du calcul des probabilités [1786-1787], which was the first to publish, from which the reader infers that the Tableau général must date from pre-revolutionary times. ${ }^{8}$ The 1847-1849 edition, established mostly by Eliza O'Connor, Condorcet's daughter, mentions that it was published on "June 22 and July 6, 1795", letting the reader infer it was published posthumously. The 1974 edition reproduces this mistake. ${ }^{9}$ The 1986 edition mentions the dates "June 29 and July 6", but no year is given. In reality, Condorcet's text came out in print for the first time in late June, or early July 1793, in a girondin newspaper, the Journal d'instruction sociale. ${ }^{10}$ Although it is hard to identify precisely the date when Condorcet actually wrote the text, it cannot have been earlier than spring 1793 [1.1.]. Those were troubled political times, which ultimately led to Condorcet himself being put under arrest. The context

\footnotetext{
${ }^{3}$ The events which led him to such an extreme choice need to be briefly reminded. Late in June 1793, he published anonymously a fierce criticism of the montagnard constitutional plan. On July 8, he was denounced by Chabot as the author of the text, and put under arrest. He took refuge in $\mathrm{M}^{\mathrm{me}}$ Vernet's house, rue des Fossoyeurs (now rue Servandoni, in Paris). He left the place on March 25, 1794, was arrested on March 27, and found dead by his gaolier one or two days later.

${ }^{4} \mathrm{~A}$ list of all editions and reprints of this text can be found in the bibliography.

${ }^{5}$ MS 885 (II), f.3 = 208. The manuscript and its transcription are presented in Appendices 1 and 2.

${ }^{6}$ Sur les sens des mots sciences et art - Sur les classifications des sciences et des arts [1793-1794], n. a. fr. 4586, f. 55-62. The text is published and commented in Condorcet, Tableau historique des progrès de l'esprit humain (1772-1794), p. 761-773.

${ }^{7}$ Fayolle [1805], p. VIII.

${ }^{8}$ It might be the reason why E. \& R. Badinter [1988, p. 241] assert that the text was written by Condorcet in 1787, though they give no argument in support of their thesis.

${ }^{9}$ As many commentators do. In the $20^{\text {th }}$ century only, see for instance F. Alengry [1904, p. 786], K. Pearson [1921-1933, p. 493], G. T. Guilbaud [1952, p. 510], G. G. Granger [1956, p. 2; 1971, p. 386], B. Valade [1989, p. 334].
} 
Condorcet's Social Mathematic - A Few Tables

had a manifest influence on the conditions in which the project of the Social Mathematic was undertaken. Some notions introduced in the Tableau général are not defined rigorously. Furthermore, the general structure of Condorcet's text is unbalanced, mostly in the second part [1.2.]. Apart from K. M. Baker, ${ }^{11}$ and perhaps Parisot, ${ }^{12}$ commentators have ignored the weaknesses and gaps in the text.

\subsection{Historical background}

The writing of the Tableau général took place in a stormy political climate. In spring and early summer 1793 the civil war was raging, abroad military defeats were multiplying, and at the Convention the tensions between girondins and montagnards were reaching a climax. Following the uprisings in Paris on May 31 and June 2, the main girondins leaders, close to Condorcet, were put under arrest. In the text, Condorcet might have been alluding directly to those troubled times when he wrote, in the midst of a development on the "results of calculus" [p. 108], that those results were a means to "calm promptly the disorders which necessarily accompany every large movement,"13 by putting an end to "the power that speech has usurped from reasoning." 14

However, it remains difficult to assess whether Condorcet wrote the Tableau général before or after the jacobin "coup" of June 2 which forced him to live a semi-clandestine life. The dates on the title-page of numbers 4 and 6 of the Journal d'instruction sociale should be taken with caution. Number 4 is dated June 29, but an errata at the end of number 5 corrects the publication dates of several issues, pushing back number 4 to June $22 .{ }^{15}$ Number 6 is dated July 6 . But, since the first issue of the Journal d'instruction sociale, dated June $1^{\text {st }}$, had been due out initially on April $6,{ }^{16}$ numbers 4 and 6 should have been published respectively on April 27 and May 11, since it was a weekly journal. One could infer that Condorcet wrote the Tableau général before the fall of the girondins.

Nevertheless, some articles published in earlier issues than, or in the same one as, the Tableau général, were written or completed after the fall of the girondins. For instance, in another text by Condorcet, Que toutes les classes de la société ont le même intérêt, published in number 2 of the

\footnotetext{
${ }^{10}$ On that periodical paper, see H. Delsaux [1931, p. 98-106], K. M. Baker [1975, p. 429 ff.], M. Dorigny [1981], [1989].

${ }^{11}$ Baker $[1975,445,501]$ declares that the Tableau général was "written in haste" and that it is "unfinished". However, he gives no evidence for those assertions.

${ }^{12}$ Parisot had read the text together with the Elémens du calcul des probabilités in the very faulty 1805 edition (cf. B. Bru \& P. Crépel [1994, p. 605 ff.]) His remarks bear on the whole work, and that statement does not apply specifically to the Tableau général. "Should I mention a short work by Condorcet, which was published recently under the title Elémens du calcul des probabilités, in Paris, by Royez, 1805 ? I would not dare to suspect the editors of abusing the public by a so-called posthumous and purely pseudonymous publication; but if the text is truly Condorcet's, then it can be nothing else than the first sketch of a work he was preparing. It is impossible to write in a more meaningless and obscure fashion.", Parisot [1810, p. xii, note].

13 [réparer promptement les désordres inséparables de tout grand mouvement], p. 108.

${ }^{14}$ [l'empire usurpé par la parole sur le raisonnement], p. 109.

15 "No 3, first page, Saturday June 22, read, Saturday June 15. Number 4 is due out on Saturday 22, and number 5 on the 29 $9^{\text {th }}$.", [p. 160]. The grammatical tenses used are inconsistent: the statement being published in Number 5, a past tense should have been used everywhere. However, this alteration stands at the end of a text by Sieyès, Du nouvel établissement public de l'instruction en France, the first part of which had been published in number 3. It seems reasonable to infer that the whole article had been due out in number 3 but had to be cut into three instalments because of its length.

${ }^{16}$ As announced in the "Prospectus" [Journal d'instruction sociale, p. 11], which was itself published only late in May 1793.
} 
Journal d'instruction sociale (that is to say before the Tableau général), there is most probably an allusion to the protest initiated by the départements in early June against the political liquidation of the girondins. ${ }^{17}$ Sieyès's article, Du nouvel établissement public de l'instruction en France was certainly written integrally between the end of June and the beginning of July, ${ }^{18}$ but published in three instalments, numbers 3 to 6 . Thus its publication began before that of the Tableau général and overlapped with it.

Therefore, the Tableau général could perfectly well have been written in June, that is to say at a time when Condorcet was almost a clandestine. What also deserves notice is that the article did not appear in consecutive issues, and that the first instalment in number 4 did not mention that the article was to be continued, which was unique among the articles published in instalments in the Journal d'instruction sociale. Therefore, one might infer that when number 4 was published, on June 29, Condorcet had not yet completed the article, or had just started writing the last section.

It is then highly probable that Condorcet wrote his article very shortly before being put under arrest on July 8, 1793. A codicological analysis also supports this hypothesis: the study of the types of papers used by Condorcet during the Revolution shows that the only remaining manuscript sheet of the Tableau général ${ }^{19}$ matches the type of sheets used by Condorcet a few weeks, or even a few days, after going into hiding. ${ }^{20}$ Despite these clues, it remains possible that the Tableau général was written at a slightly earlier date, around May 1793.

Whatever the precise date, it was written in a troubled and unstable political situation, in the run up to the Terror which eventually claimed the life of the encyclopédiste. As we shall see, this specific context put pressure on Condorcet's project.

\subsection{Textual difficulties}

Condorcet's writings in pure mathematics are rightly famous for their obscure style, but this is not the case of his literary essays, to which the Tableau général belongs. With the exception of some

\footnotetext{
${ }^{17}$ This allusion was noted by H. Delsaux [1931, p. 105]: "I shall speak first of the so-called opposition of interests [...] between a town which has become a national chef- lieu in the facts, and the rest of the land: we know that [this mistake is], today, one of the main causes of the storms we are going through, and of the evils which threaten to befall us." [Je parlerai d'abord de la prétendue opposition d'intérêts [...] entre une ville devenue le chef-lieu national par le fait, et le reste du territoire: on sait que [cette erreur est], dans ce moment, une des principales causes des orages qui nous agitent, des maux dont nous sommes menacés], Journal d'instruction sociale, n², p. 51 .

${ }^{18}$ Sieyès's text was a commentary on the project on public instruction presented to the Convention by Lakanal on June 26, 1793, which was amended on July 1 and finally rejected after debates which took place on July 2 and 3. In the first part of his article, Sieyès mentions that the Comité d'instruction publique, of which Lakanal was the spokesman, had "just presented" a project, but he mistakenly gives the date of June 25 for that event which took place on June 26. This figures in number 3, which was antedated June 22, and then June 15, 1793. In number 6 , which is dated July 6 on the title page, Sieyès mentions that the project was presented to the Convention "three or four days ago", p. 164. For more details on Lakanal's project, see J. Guillaume [1891], p. 506-507.

${ }^{19}$ MS 885 (II), f. $3=208$. See Appendix 1 for a material description of the folio. The type of paper used is referenced as "BIF 003" in the MUSE database (manuscripts and material supports of written texts) compiled by C. Bustarret and S. Linkès (ITEM, CNRS).

${ }^{20}$ i.e. the sheets used for the "Plan de 1793" [n. a. fr. 4586, f. 1] and for the beginning of the "Prospectus" [MS 885 (III), f. $377-388$ ] of the Tableau historique. See Condorcet, Tableau historique des progrès de l'esprit humain (1772-1794), p. 1231.
} 
Condorcet's Social Mathematic - A Few Tables

manuscript drafts, the Tableau général is one of his most difficult writings. Let us first present its general outline [p.105-128, 166-184]:

- General introduction [p.105-110]

- Presentation of the objects of the Social Mathematic [p. 110-112]

- Presentation of the method of the Social Mathematic [p. 112-116]

- Reminder of the five preliminary theories [p. 116-117]

- The Social Mathematic as a branch of knowledge accessible to the greatest number [p. 117-118]

- Synoptic table [p. 119], [blank page] [p. 120]

- Application to men [p. 121-128]

- Application to things [p. 166-182]

- Relations between political economy and the Social Mathematic [p. 182-184]

In order to understand the contents of the Tableau général, it is necessary to start from the synoptic table on p.119 and to reconstruct the text from that general outline, in which Condorcet is supposed to provide the framework for the written text. The pages before the table [p. 105-118] are on the whole quite clear and readable, despite some noticeable ambiguities. However, the text after the table gets less and less consistent and finishes with epistemological considerations which do not provide an obvious conclusion to the essay, as if the writer was becoming a "process writer" instead of the "programme writer" he had always been. ${ }^{21}$ Indeed, he seems to be writing just as the ideas come to him, developing them as they come. These various aspects will be explained in detail; most of them are due to the haste in which the Tableau général was written.

Especially in the part of the text which precedes the synoptic table, describing the various phases of his project, Condorcet does not seem to have chosen his words carefully, which reveals that the Tableau général was written cursorily. He singles out two large categories. The first one is devoted to the "objects" of the Social Mathematic, "men, things, or men and things together."22 The second relates to his "method" and consists of "the determination and appreciation of the facts and [...] their results." ${ }^{23}$ Then, Condorcet lists explicitly the various elements contained under each title, calling them "parts" [p. 112, 166], or "portions" [p. 112, 182], of the Social Mathematic. Later, the categories devoted to men, that is to say to men as "individuals" and "minds" [p. 110-111], are presented as "the first two parts of the social mathematic." ${ }^{24}$ The fact that they are presented as "parts" and not as "subparts" is only slightly ambiguous. However, the classification becomes murkier when one of the

\footnotetext{
${ }^{21}$ The distinction between "écrivain à processus" and "écrivain à programme" is borrowed from L. Hay [1984], p. $318,320$.

22 [les hommes, les choses, ou à la fois les choses et les hommes], p. 110.

23 [la détermination des faits, leur évaluation [...] et les résultats des faits], p. 112.
} 


\section{Condorcet's Social Mathematic - A Few Tables}

five preliminary theories of the Social Mathematic, the "general theory of probabilities", is presented as "both a portion of the science under examination and one of the foundation stones of all others." 25 Things get even more complex if we take into account the passage in which Condorcet claims that "the theory of the reduction of values to a common standard", which is not one of the five preliminary theories, must be considered "an essential part of the social mathematic."26

In the above quotes, Condorcet uses the words "parts" or "portion" in five different meaning. Such polysemy seems quite disconcerting at first sight. If Condorcet had established the final version of his text after several series of rereading and amendments, less semantic variations would have remained. We shall try to make them clearer later.

Another clue suggests that the Tableau général was written in -almost- one go: the three objects of the Social Mathematic are unequally developed. It is true that Condorcet was only attempting to sketch the outline of his research, without developing all its branches. After presenting two of the subparts of the Tableau général devoted to man as "an individual" and as "a mind", he admits that he has only given a "very imperfect sketch." ${ }^{27}$ But even though the Tableau général is nothing but the prospectus for a larger project, it is surprising to note that Condorcet deviates from his original intention in presenting only two of the three objects of the Social Mathematic: as applied to men [p. 21128], to things [p. 166-182], but not as applied to men and things together.

In his work on Condorcet's Social Mathematic, G. G. Granger [1956, p. 152] considers the third object as a "blind window [...] masking the true organisation of the parts of the building without modifying its general plan, which remains perfectly clear and consistent." According to his reading, there would be only two fields in Condorcet's inquiry, those devoted to men and to things. As we shall see, the third field presented by Condorcet is not in the least a "blind window". We shall only note here that Granger did not take into account the specific circumstances in which the Tableau général was written and published, and which rather point in the direction of an unfinished essay. The publication of the Tableau général was interrupted after the second instalment, on July 6, 1793, only two days before Condorcet was put under arrest by the Convention: that was to be the last issue of the Journal d'instruction sociale. Did the published version of the text correspond partially or integrally to the manuscript? Only one draft of the synoptic table remains [appendix 1]. K. M. Baker [1975, p. 445] asserts that the essay remains unfinished, but does not substantiate this claim. However, the last sentence of the second published part sounds like a conclusion, ${ }^{28}$ and there is no hint in the Journal d'instruction sociale that there ever existed a more substantial manuscript version. One can conclude

\footnotetext{
24 [les deux première parties de la mathématique sociale], p. 128.

${ }^{25}$ [la théorie générale de la probabilité [...] une portion de la science dont nous parlons, et une des bases de toutes les autres], p. 112.

26 [la théorie de la réduction des valeurs à une mesure commune [...] une partie nécessaire de la mathématique sociale], p. 111 .

27 [une esquisse très imparfaite], p. 128.

28 "I venture to hope that a combined attack by reason and calculus will finally remove all threat of both these unexpected resurrections and these oscillations between truth and error" [Osons espérer qu'attaqués par la raison et le calcul, nous n'aurons plus à redouter ces résurrections inattendues, ces oscillations entre la vérité et l'erreur.], p. 184.
} 
that Condorcet never wrote the end of the Tableau général, which would have been especially devoted to the application of the calculation to men and things together.

Several conclusions can be drawn at this point. Condorcet wrote the Tableau général in haste during a few days in spring-summer 1793 (probably in June, and possibly in early July), just before he was put under arrest. He did not have enough time to finish or polish it. That is the reason why many passages remain elliptical, or even equivocal, and why the structure of the essay is unbalanced. But these are not the only reasons why the Tableau général is difficult to read: editorial blemishes were added to those contained in the manuscript, especially in the first edition. This is what we shall focus on in the next part, while presenting the genuine structure of Condorcet's text.

\section{OBJECTS, METHODS AND PRELIMINARY THEORIES}

A part from a few insignificant misprints ${ }^{29}$ the poor editorial quality of the Tableau général is due to the state of the synoptic table, which should provide a central tool for understanding the Social Mathematic. More specifically, the heading devoted to the "method of the science" has been misrepresented from the first edition of Condorcet's text onwards, even though central to the understanding of the text. Indeed, it defines the Social Mathematic in relation to traditional political arithmetic, and makes up the second part of the Tableau général, the first being devoted to its objects. The poor state of the text in the first edition has become even worse in subsequent editions, as if transmitted by bush telegraph. We shall try to correct these editorial mistakes by reproducing the Tableau général in its two dimensions [2.1]. Because most of them are associated with the "method of the science," the preliminary theories of the Social Mathematic as they appear in the synoptic table for Condorcet's project seem to have suffered the same editorial fate. These blemishes are all the more harmful to the understanding of the Social Mathematic as Condorcet, in the body of the text, remains quite secretive about the contents of the various preliminary theories. The reason might be that he is writing cursorily, or else that he estimates that such explanations are not required for the readers of the Journal d'intruction sociale. ${ }^{30}$ Whatever the reason, we shall focus on the contents of each of these theories [2.2], and from there establish the link between the "method" of the Social Mathematic and the preliminary theories, by comparing the printed essay with our restored version of the synoptic table [2.3].

\footnotetext{
${ }^{29}$ Journal d'instruction sociale, $\mathrm{n}^{\circ} 4$, p. 105, line 21, read "dont la liberté a eu " instead of "dont la liberté ait eu "; p. 116, line 16, read "application particulière du calcul " instead of "application particulière en calcul "; p. 124, line 21, read "syllogistique" (or "sillogistique") instead of "sollogystique"; p. 125, line 25, read "pyrrhonisme" (or "pirrhonisme") instead of "perrhonisme"; page 127, line 15, read "atteinte" instead of "atteint"; page 127, line 16, read "la" instead of "le"; Journal d'instruction sociale, n 6 , p. 172, line 16, read "ordinaires" instead of "ordinaire"; p. 176, line 12, read "de calculer" instead of "de calcul"; p. 179, line 10, read "Cependant si ce dérangement" instead of "Cependant ce dérangement"; p. 184, line 6, read "n'apprendrait" instead of "n'apprendra".

${ }^{30}$ See H. Delsaux [1931, p. 103], K. M. Baker [1975, p. 429-430].
} 


\subsection{Double entry: Objects and Method}

The Tableau général is built around two entries, the first devoted to the objects of the Social Mathematic, the other to its method. To illustrate the first of these two headings, Condorcet lists the areas to which it can be applied:

"It [the Social Mathematic] has men [as individuals and as minds] for its object, when it teaches us to work out the mortality rate in a particular area, when it calculates the advantages and or the disadvantages of an election method. It has things for its objects when it calculates the advantages of a lottery, or tries to determine the principles on which the rate of maritime premiums should be based. It has both men and things for its object when it examines life annuities and life insurance." 31

The list of fields echoes the entire work of the Académicien. ${ }^{32}$ His writings devoted specifically to election modes ${ }^{33}$ or to maritime insurance ${ }^{34}$ can be easily isolated, but his reflections on the duration of human life are understandably linked to those devoted to life annuities ${ }^{35}$ or life insurances ${ }^{36}$. In the same way, though some works are devoted exclusively to lotteries, ${ }^{37}$ Condorcet notes that lotteries are linked to life annuities in so far as life annuities can be won at lotteries. ${ }^{38}$

The existence of these numerous works proves that the third field of application of the Social Mathematic represents a central part of it, which Condorcet can easily explain and illustrate. It is not in the least an empty category, or a "blind window", to repeat G. G. Granger's phrase [1956, p. 152]. It is neither made up of the remaining parts, or of all the applications which are not covered by the first two

\footnotetext{
${ }^{31}$ [Elle [la Mathématique sociale] a les hommes pour objet [respectivement "en tant qu'individu" et "en tant qu'esprit"], lorsqu'elle enseigne à déterminer, à connaitre l'ordre de la mortalité dans telle ou telle contrée, lorsqu'elle calcule les avantages ou les inconvénients d'un mode d'élection. Elle a les choses pour objet lorsqu'elle évalue les avantages d'une loterie, et qu'elle cherche d'après quels principes doit être déterminé le taux des assurances maritimes. Enfin elle a en même temps l'homme et les choses pour objet, quand elle traite des rentes viagères, des assurances sur la vie.], p. 110.

${ }^{32}$ A critical edition of Condorcet's works written between 1767 and 1789 relative to the applications of calculus to political and morals sciences (excepting the Essai sur l'application de l'analyse [1785] and the Elémens du calcul des probabilités [1786-1787]) can be found in B. Bru \& P. Crépel [1994]. Those written during the revolutionary period are presented in P. Crépel [1990]. A study of these works together with the Tableau général reveals other fields which can be added to those mentioned here by Condorcet: means of deliberating, theory of knowledge... (men); insurances against natural hazards or fire, casual rights, taxes, interests, loans in general... (things); tontines, substitutions, problème de l'absent... (men and things).

${ }^{33}$ References on this topic are numerous, we will therefore only mention the two main works devoted to the subject, the Essai sur l'application de l'analyse [1785] and the Essai sur les assemblées provinciales [1788], Part I, Art. V \& Note 1. For a full list of texts on elections, see P. Crépel [1990].

${ }^{34}$ Précisions sur le programme du prix relatif aux assurances maritimes [around 1783], BC, p. 467-469; Assurances maritimes [1784], BC, p. 485-494.

${ }^{35}$ Principes pour calculer les loteries partie en rentes perpétuelles, partie en rentes viagères [1777 or later], BC, p. 589-594; Probabilité [1785], BC p. 507-509; Fragments sur les rentes viagères [1786-1787], BC, p. 615-617; Application du calcul des probabilités aux questions où la probabilité est indéterminée [1786-1787], BC, p. 623-625.

${ }^{36}$ See Lettre de Condorcet et de Laplace au baron de Breteuil [July 12, 1787, BC, p. 642-644], Rapport de Condorcet et de Laplace sur le projet d'assurance-vie de Beaufleuri [1790, BC, p. 644-645], and Lettre de Condorcet à Duvillard [1790?]. See also Condorcet's writings on stock funds, which are established to cover death hazards and are thereby linked to mortality tables. See especially Sur les caisses d'accumulation [1790, OC, vol. XI, p. 389-403], Mémoires sur la fixation de l'impôt [1790, OC, vol. XI, p. 430-433], Rapport et projet de décret sur l'organisation générale de l'instruction publique [1792-1793, OC, vol. VII, p. 560], Esquisse [1793-1794, p. 437439].

${ }^{37}$ Manuscrit sur les loteries [1784?, BC, p. 553-556], Elémens du calcul des probabilités [1786-1787, p. 560-561, 565-579, 591-596].
} 
Condorcet's Social Mathematic - A Few Tables

objects of the Social Mathematic. The reason no specific development is devoted to it in the part which follows the synoptic table of the Tableau général is that, according to the most likely hypothesis, Condorcet wrote the text in haste, and didn't have enough time to finish or polish it.

As far as we know, studies of Condorcet's Social Mathematic do not draw attention to its twodimensional nature, that is to say to the fact that the heading "objects" interacts with the "method" heading, to which we have referred. However, this method allows Condorcet to present the specificity of the discipline he intends to promote: "whatever the object of this science, it comprises three main parts; the determination of the facts, their appreciation, which includes the theory of average values, and the results of the facts. He adds that in each of these parts, after considering the facts, the average values and their results, there remains to determine their probability." ${ }^{139}$

Because of its hypothetical aspect, the second entry in the Tableau général constitutes the distinctive feature of political arithmetic according to Condorcet. ${ }^{40}$ Indeed, traditionally political arithmetic (if we except its demographic side) covers a field which is roughly commensurate with what we call national book-keeping (counting inhabitants, estimating their life expectancy, calculating the balance of national trade, consumption, production, revenues from taxation, and distributed income...). Condorcet does not challenge the importance of these objects of investigation, but he locates them in the sphere of probability. In that way, the place of some of these objects is systematised, or at least, other elements are added to them. Research into lotteries, mortality tables, life annuities, insurance, elections or deliberation modes thus forms an essential part of the Social Mathematic, each of these objects being placed under the following headings: men, things, and men and things together.

This understanding of the way in which mathematics can be applied to political sciences is not new for Condorcet. It follows a train of thought which started more than twenty years before he wrote the Tableau général. In a manuscript which dates back to 1772 , he writes that probability theory is the key to the distinction between two definitions of political arithmetic. "Two meanings can be ascribed to it: either the exact examination of the number of men, of the duration of their lives, of the size of plots, of the amount of revenue, of money, of taxes, etc., which are to be found in a state. In this sense, it is purely a science of facts. Or by it we can mean the fact that, once those facts are established by the calculus just mentioned, one must conduct oneself as regards future events according to the probability calculus." ${ }^{41}$ In three later texts, ${ }^{42}$ Condorcet defines more precisely the second meaning he ascribes to the word: $1^{\circ}$ determination of the facts, $2^{\circ}$ results of the facts, $3^{\circ}$ probability of the facts and results.

\footnotetext{
${ }^{38}$ Principes pour calculer les loteries partie en rentes perpétuelles, partie en rentes viagères [1777 or later, $\left.\mathrm{BC}, \mathrm{p} .589-594\right]$.

${ }^{39}$ [quel que soit l'objet que cette science considère, elle renferme trois parties principales; la détermination des faits, leur évaluation qui comprend la théorie des valeurs moyennes et les résultats des faits [...] dans chacune de ces parties, après avoir considéré les faits, les valeurs moyennes ou les résultats, il reste à en déterminer la probabilité.], p. 112.

${ }^{40}$ On this point see P. Crépel [1988, p. 268-269] and J. N. Rieucau [2005 a].

${ }^{41}$ BC, p. 303.
} 


\section{Condorcet's Social Mathematic - A Few Tables}

The method described in the Tableau général is close to this definition, in spite of the fact that Condorcet explicitly places average values in a conjectural perspective, as something which can stand for all "the observable facts or those which are regarded as equally possible." ${ }^{43}$ The strongly probability-based method of the Social Mathematic thus allows Condorcet to go beyond the traditional definition of political arithmetic.

We shall come back later to the nature of his method and its links with the preliminary theories of the Social Mathematic. Here, we need to restore the two-dimensional nature of the synoptic table in the Tableau général, hints of which are already present in Condorcet's manuscript draft [appendices 1, 2]. In a simplified version, the two branches of the Social Mathematic could be presented in this way:

\section{OBJECTS OF THE SOCIAL MATHEMATIC}

$\begin{array}{cc}\text { I. } & \text { II. } \\ \text { Man } & \text { Things }\end{array}$

III.

Man and things together

\section{METHOD OF THE SOCIAL MATHEMATIC}

I.

II.

Determination of the facts Appreciation of the facts

III.

Results of the facts

The above table is faithful to the way in which it is presented in the Tableau général. It is also possible to present it in a different way, by distributing the headings into "lines and columns":

\footnotetext{
${ }^{42}$ Réflexions sur l'arithmétique politique [around 1780], BC, p. 337; Arithmétique politique [1784], BC, p. 483; Rapport et projet de décret sur l'organisation générale de l'instruction publique [1792-1793], OC, vol. VII, p. 557-558.

${ }^{43}$ [des faits observés ou regardés comme également possibles], p. 116.
} 


\begin{tabular}{|l|l|l|l|}
\hline METHOD & Things & Men and things \\
\hline Determination of the facts & & & \\
\hline Appreciation of the facts & & & \\
\hline Results of the facts & & & \\
\hline
\end{tabular}

Even though the above model does not correspond to the canonical way in which "tables" were presented in the $18^{\text {th }}$ century, Condorcet was familiar with it. In "note $9^{44}$ of the Tableau historique des progrès de l'esprit humain he suggests that it can be constructed, and he uses it himself in some passages on the division of analysis. ${ }^{45}$ In the present case, such a mode of representation can only be used to reflect the two-dimensional nature of Condorcet's project. In fact, the contents of each of the three parts of the synoptic table of the Social Mathematic, as we have restored it [Appendix 3], cannot be fitted properly into it.

Although the ramified structure proves very useful, it has been extremely poorly printed, even in the first edition. The two headings come out in incorrect characters in the first edition: different characters are used for the "OBJECTS" (in upper case) and the "method of the science" (in italicised lower case), whereas they should appear at the same level. The two headings are correctly separated by a horizontal line, but the distinction is blurred by the fact that two extra horizontal lines of the same

\footnotetext{
${ }^{44}$ Exemple des méthodes techniques, p. 1042-1043.

${ }^{45}$ Division de l'analyse [w. d.], in E. Brian [1994, p. 219].
} 
size (where they should logically be smaller) appear in the heading devoted to the "Determination of the facts."

The subsequent editions of the Tableau général continued to hide even more the twodimensional aspect of Condorcet's project. The unpublished letters of Sophie de Grouchy ${ }^{46}$ and Eliza $\mathrm{O}^{\prime}$ Connor ${ }^{47}$ testify that they considered the text published in the Journal d'instruction sociale as a reference for their own editions. But, because the division between "objects" and "methods" was blurred in the first place, they simply missed it altogether. In the 1804 text [Appendix 5], under Sophie de Grouchy's editorship, the line which separates the two entries disappears. The "method of the science" seems therefore to be no more than a sub-heading of the "third object", that of "men and things", which does not make sense. The meaningless insertion of the method of the science within the third field of application of the Social Mathematic is reinforced by the typographic layout of Eliza O'Connor's edition in 1847-1849 [Appendix 7], and even further by the 1974 edition by R. Rashed [Appendix 8], which is inspired by the former. The English translation by I. McLean and F. Hewitt [1994] [Appendix 10], which is also based on O'Connor's text, not only misplaces the method of the Social Mathematic within the synoptic table, but also mistranslates it as "scientific method".

Poor as those editions might be, they are much better than that of 1805 on which the 1986 and 1997 texts are based. Compared to the article published in the Journal d'instruction sociale, it contains around twenty misprints and inaccuracies, the list of which it would be too tiresome to give here. Some words are substituted for others, ${ }^{48}$ parts are missing in several sentences ${ }^{49}$ and one of the logical divisions present in the 1793 original have disappeared. ${ }^{50}$ What is more, the synoptic table is presented in an incoherent way [Appendix 6]. Firstly, it is not detached from the text and printed separately as an insert, but cut between two half-pages. Secondly, the "result[s] of the facts" heading, which should be one of the three divisions of the "method of the science", has become a first-rank heading (in upper case) and is presented at the top of the page. As such, it could be understood as opening a new chapter, and as not belonging to the table. That is how it was interpreted by the editor in 1986 [Appendix 9],

\footnotetext{
${ }^{46}$ Lettres à A. A. Barbier [6 nivôse an VII (Dec. 26, 1798)], n. a. fr. 1390, f. 293 r and [29 nivôse an VII (Jan 18, 1799)], n. a. fr. 1390, f. $291 \mathrm{r}$, in J. N. Rieucau [2005 b].

${ }^{47}$ Lettre à L. Barbier [July 25, 1845], n. a. fr. 1390, f. 307 r.

${ }^{48}$ For instance, p. 179, line 5, read "liste des combinaisons" instead of "suite des combinaisons"; p. 200, line 19, read "10 000 livres" instead of "10 000 francs"; p. 203, line 31, read "défense commune" instead of "déférence commune".

${ }^{49}$ Bracketed segments in the following quotes are missing from the 1805 edition (only major omissions are given here): p. 191, line 10: "tel est celui de former ou de deviner les chiffres; [telles sont les machines arithmétiques,] "; p. 192, line 4: "on distingue [celles qui expriment le vœu de préférence de la majorité]"; p. 194, line 7: "vingt-cinq mesures de vin en valent cinquante de blé, [et en conclure que celui qui a cinquante mesures de vin, celui qui a vingt-cinq mesures de vin \& cinquante de blés]"; p. 195, line 4: "supposant qu'un couteau vaut deux peaux, [et qu'une hache en vaille vingt]"; page 201, line 15: "une foule d'opérations diverses, [dont le but est la circulation des valeurs,] et dans lesquelles on emploie nécessairement le calcul [. C'est donc ici que l'on doit placer l'application du calcul] aux opérations de commerce et de banque"; p. 208, line 10: "qui nécessitent [le recours au calcul des probabilités] ".

${ }^{50}$ p. 188, line 23: the figure "II" is missing in front of the sub-heading of the Social Mathematic devoted to "intellectual operations."
} 
who was taking the 1805 text as a reference. Unfortunately, this grossly distorted version ${ }^{51}$ happens to be the version of Condorcet's text of which the greatest number of copies have been printed.

We have attempted to reconstruct [Appendix 3] what the original synoptic table of the Tableau général should have been, by showing it in its two branches, in a way which conforms to the original 1793 edition [Appendix 4] and to the draft manuscript sketch remaining [Appendices 1, 2]. In this way, we have tried to represent accurately the preliminary theories of the Social Mathematic, which are closely linked to its method. These theories are to be studied next, with a detailed inventory of the mutilations and misprints they suffered in various published editions.

\subsection{Preliminary theories}

Condorcet indicates that the five "mathematic theories" that should precede the Social Mathematic must be:

"The theory of quantities, which can increase in proportion to time, and includes the theory of money interest.

The theory of combinations.

That of the method for deducing from observed facts either general facts or even more general laws.

The theory of the calculus of probabilities.

And lastly that of average values." 52

Condorcet's meaning must be understood literally: these five theories exist independently from political and moral sciences, but are indispensable in applying calculus to those sciences. He follows the usual method of scientists in the field of "mixed mathematics" 53 who first present the preliminary theories they are about to use.

It is not surprising that geometry, number theory and the differential and integral calculus should not be mentioned. Condorcet did not believe that they could be systematically applied, at least as mathematics and the political and moral sciences stood, which was indeed true at Condorcet's time.

We shall now examine these theories in turn, explain their content where necessary, and show the way they are used in Condorcet's writings, and in those of his contemporaries.

\footnotetext{
${ }^{51}$ We invite our readers to "spot the differences" between the table reproduced in the Tableau général in the 1986 edition [Appendix 9] and that of 1793, which was faulty already [Appendix 4].

52 [La théorie des grandeurs, susceptibles d'accroissements proportionnels au tems, qui renferme celle de l'intérêt de l'argent. // La théorie des combinaisons. // Celle de la méthode de déduire des faits observés, soit les faits généraux, soit les lois plus générales encore. // La théorie du calcul de probabilités. // Enfin celle des valeurs moyennes.], p. 116-117.

53 This is roughly what is today called "applied mathematics", though the phrase "mixed mathematics" gives a more accurate idea of the interaction between mathematics and the field to which they are applied.
} 
1) The theory of quantities, which can increase in proportion to time, and includes the theory of money interest

This theory could be found in almost all algebra books and articles ${ }^{54}$ and does not involve probability theory. As a preliminary theory, it is presented by Condorcet in the "First article" of his Elémens du calcul des probabilités, written in 1786-1787, but unpublished at the time the Tableau général came out. In the Elémens, the various formulae of compound interest established by Condorcet ${ }^{55}$ often come with considerations on the safe and profitable character of such investments for modest families. In taking up again this theory in the Tableau général, he might have had in mind the theories of Duvillard de Durand whose Recherches sur les rentes, les emprunts et les remboursemens [1787] could have led his contemporaries to use differential calculus for such purposes. ${ }^{56}$ This book was well known to Condorcet, since he had written a report on it for the Académie des sciences and contacted Duvillard on that occasion. ${ }^{57}$ One should note that Duvillard was, among Condorcet's circle, one of the main promoters of the application of calculus to political and moral sciences, even though it cannot be inferred, as some have done, that he contributed to the writing of the Tableau général. ${ }^{58}$

\section{2) The theory of combinations}

As a purely algebraic theory, this involves counting "combinations" (as its name shows), the calculus of arrangements, permutations, Pascal's arithmetic triangle, etc. The theory also provides, of course, the indispensable algebraic basis for the calculus of probabilities on finite sets, since the probability of an event corresponds to the ratio of the number of favourable cases to the number of possible cases, a definition which was widely known and accepted in Condorcet's time. In the Académicien's writings, the theory of combinations meets what he calls "technical methods" of classification - which can bear on objects as various as minerals, plants, animals or even men - to the extent that, like every nomenclature, these methods display the various arrangements of a number of features. Condorcet develops his theory of classifications, which he often presents in a decimal mode, in "Note 9" ("Exemple des méthodes techniques") of the Tableau historique, as well as in "Article II" ("Sur une méthode de former des tables") of the Elémens du calcul des probabilités.

\footnotetext{
${ }^{54}$ For books devoted to this topic, see La Chapelle [1765], Trincano [1781]. Major articles include d'Alembert [1751 b], Rallier des Ourmes [1765].

${ }^{55}$ For a commentary of these formulae, see P. Crépel [1988].

${ }^{56}$ See Y. Biondi [2003], Part 1, $\$ 4$.

${ }^{57}$ In his Souvenirs, [around 1813-1814, p. 31] Duvillard wrote: "this book earned me the esteem and friendship of the illustrious and unfortunate Condorcet. He wrote a report [on it] for the Académie [...], which adopted his conclusions with the most flattering and distinct approval."

${ }^{58}$ In Première esquisse du tableau général de la mathématique sociale [1816, p. 314], Duvillard himself insists that the phrase "Social Mathematic" has been coined by Condorcet in the 1793 Tableau général, from which we must infer that he did not contribute to writing it, which is not surprising since he never wrote in the Journal d'instruction sociale. Further, when he borrows from the Tableau général in his Première esquisse, he copies it literally, which leads him to commit several anachronistic mistakes. For instance, he claims that the
} 
3) The method for deducing from observed facts either general facts or even more general laws

This "method", which is especially dear to Condorcet, has been underestimated by commentators. The first explicit allusion to his interest in the subject is the enthusiasm visible in his report to the Académie des Sciences on March 26, 1774, on Lagrange's book Sur la manière de former des tables des planètes par les seules observations ${ }^{59}$ [1773]. Condorcet came back to it for the review he wrote in 1774 for the Histoire de l'Académie for the year $1772 .{ }^{60} \mathrm{He}$ also mentions the "method" in an original and personal work, the Essai d'une méthode pour trouver les loix des phénomènes d'après les observations [1775-1776]; and in his Mémoire sur le calcul des probabilités, "Fourth part" [1786] (especially in section VIII). It is at the same time a mathematical theory of induction and an algebraic process, based on determinants, which aims at drawing curves within a scatter of points and could be compared to today's theories of regression and approximation. The third preliminary theory, like the second one, requires a preliminary process of classification (insofar as establishing general facts or general laws involves grouping together several sets of data according to one or more criteria). ${ }^{61}$ In Condorcet's writings, this issue involves relatively technical developments on probabilistic errors and a philosophical reflection on the "constancy of laws".

\section{4) The theory of the calculus of probabilities}

It is not surprising that this theory should be involved here, because Condorcet's Social Mathematic, as we have seen, is intrinsically probabilistic. We shall only recall briefly that, from as early as 1774 in his presentation of Laplace's writings, the Mémoire sur la probabilité des causes par les événemens, Condorcet had underlined and defended publicly the possibility of applying calculus, through probability theory, to the political and moral sciences.

In that respect, appealing to the probability calculus in political and moral sciences poses specific difficulties, because collecting data is more problematic than in the physical sciences. In these fields, Condorcet contends that the use of probability theory is mostly necessary to make up for insufficient means of observation. In astronomy, the use of the theory of errors illustrates this fact. There is no hint, in Condorcet, of anything comparable to Maxwell's statistical mechanics, or "essential" probabilistic considerations in physics. However, as Condorcet writes in the Tableau général, the application of the probability calculus to political and moral sciences should especially render it possible "to show that, in reasoning, people have often forgotten to take into account data which should not have been ignored, and finally, that this mass of operations carried out independently

\footnotetext{
Social Mathematic could be used to assess the consequences of the destruction of Ancien Régime institutions [p. 355], or he takes up physiocratic phrases [p. 351, 359] which are outdated in the early $19^{\text {th }}$ century.

${ }_{59}$ See BC, p. 106-107. Lagrange's text as such is interesting for mathematicians. It was studied in particular by M. Galuzzi [1995].

${ }^{60}$ The text can be found in BC, p. 107-109.

${ }^{61}$ On that point, see Éloge de Jussieu [1777], OC, vol. II, p. 257-258 and Exemple des méthodes techniques [1793-1794], p. 1037-1039, 1044.
} 
Condorcet's Social Mathematic - A Few Tables

by a large number of men, and directed by interest, by opinion, or, as it were, by individual instinct, has often been assumed to exhibit an order and regularity which it could not possess." 62

\section{5) The theory of average values}

Although linked to the preceding theories, this is not reducible to them. Using average values is of course indispensable in calculating the barycentre in geometry and in mechanics, and central to the theory of expectation in probability. However, Condorcet believed that this subject could become an autonomous discipline, on condition that it were associated with the theory of approximations and the theory of errors, ${ }^{63}$ as they would come to be known in the $19^{\text {th }}$ century. In that respect, Lagrange's Mémoire sur l'utilité de la méthode de prendre le milieu entre les résultats de plusieurs observations [1770-1773], and Jean III Bernoulli's more general presentation in the article on "Milieu" [1777] in the Supplément de l'Encyclopédie (taken up again the Encyclopédie méthodique), are central. Condorcet had read these texts and appreciated them.

To what extent are the several preliminary theories relevant to the Social Mathematic, and, more specifically, to the implementation of its specific method?

\subsection{The "method of the science" and its link with the five preliminary theories}

Within the Social Mathematic, the first of the five preliminary theories, devoted to "quantities which can increase proportionally" [p. 119], is necessary because time must be taken into account when one is estimating the value of something: the value depends on whether the thing is available immediately, or during a given period, or only later. Once this estimate has been made, calculus can be applied. When it is printed and located accurately in the table of the Social Mathematic, this theory comes under the heading devoted to "objects", that is to say the application of the calculus to "things", because it is what allows them to be estimated. Since it is not linked to the "method of the science" on which we are focusing here, we shall not develop it further. However, it should be noted that when Condorcet deals with the appreciation of "things" he does not dodge the thorny question of the determination of an invariable standard of values, as it came to be called. ${ }^{64}$

\footnotetext{
62 [de faire voir que souvent on a oublié d'avoir égard, dans le raisonnement, à des données qu'il ne pouvait être permis de négliger, et qu'enfin, dans cette masse d'opérations exercées, d'une manière indépendante, par un grand nombre d'hommes, et dirigées par l'intérêt, par l'opinion, pour ainsi dire, par l'instinct de chacun d'eux, on a supposé un ordre, une régularité dont elles n'étaient pas susceptibles.], p. 177.

${ }^{63}$ On that point see the "First Part" [1784] of the Mémoire sur le calcul des probabilités.

${ }^{64}$ To that extent, the"theory of the reduction of values to a common standard" [la théorie de la réduction des valeurs à une mesure commune, p. 111] takes part in the Social Mathematic. However, Condorcet does not go as far as addressing the issue of the variableness of the commercial value of the unit taken as a standard [p. 172]. In the Tableau général, his ideas are less detailed than in the early pages of the Premier mémoire sur les monnaies [1790].
} 


\section{Condorcet's Social Mathematic - A Few Tables}

In contradistinction to the theory of "quantities which can increase proportionally", the next four preliminary theories are linked directly to the "method of the science". Indeed, they are connected with the preliminary operations to which must be submitted the facts to which the method is applied. According to Condorcet, as we have seen, there are "three main parts" -or "steps", as we shall call them here - "the determination of the facts, their appreciation [...] and the results of the facts" [p.112].

\section{Step 1. The determination of the facts}

More clearly explained in the surviving sheet than in the original 1793 edition, the step devoted to the determination of the facts consists, in the first place, of their "enumeration". Two "species" of facts can be enumerated: "observed facts" 65 and "hypothetical facts" ${ }^{66}$. For Condorcet, though, those are not entirely "pure" species of facts: except for theoretical exceptions, the facts which are the objects of the Social Mathematic are produced simultaneously by observations and hypotheses. More simply, Condorcet is aware that the choice of the facts under consideration is not neutral, nor external, but that some work is necessary to put them together. Therefore, alongside the enumeration process, a classifying process, if only an elementary one, must be conducted. For instance, when collecting data relative to mortality, one must decide if the data are to be collected daily, monthly, or yearly, etc., which means classifying a priori. ${ }^{67}$

Once the facts have been enumerated, their determination involves two operations. Firstly, "pure" hypothetical facts have to be combined, and secondly observed facts must be specifically classified. In his printed text, Condorcet presents the two operations in a somewhat roundabout way: "the general means of classifying observed facts according to the order we need to attribute to them, and of grasping easily the relationships between them, is to those facts, what the theory of combinations is to hypothetical facts." ${ }^{68}$ Both operations (classification and combination) play a similar role. But it is clear that, in dealing with concrete facts, both are often interwoven, as the printed text clearly shows [p. 112-114].

All in all, the step which consists of "the determination of the facts" can be roughly divided in the following way: "1 ${ }^{\circ}$ Enumeration. $2^{\circ}$ Classification and/or combination." As we have noticed when presenting the preliminary theories, the operation of combining obviously involves the eponymous theory, which bears number "(2)" in the printed table, whereas the theory of classification involves the second and the third preliminary theories, to which the bracketed numbers in the table refer.

\footnotetext{
${ }^{65}$ Condorcet had initially written about "natural facts" [faits naturels]. In the Tableau général, there is only one occurrence of that phrase [Journal d'instruction sociale, p. 123]. In most cases, as in the manuscript, Condorcet uses rather the phrase "observed facts" [p. 113$117]$.

${ }^{66}$ MS 885 (II), f. $3=208$.

${ }^{67}$ Besides, in the fifth and sixth parts of his Mémoire sur le calcul des probabilités, published in 1787, Condorcet insists on similar points when dealing with the probability of extraordinary facts. BC, p. 431-448.

${ }^{68}$ [le moyen général de classer les faits observés suivant l'ordre qu'on a besoin de leur donner, et de pouvoir saisir facilement les rapports qu'ils présentent, est pour ces faits, ce que la théorie des combinaisons est pour les faits hypothétiques.], p. 113-114.
} 


\section{Condorcet's Social Mathematic - A Few Tables}

In the Tableau général, Condorcet develops the first and third relationships. For the first one, the theory of combinations plays a role in the study of hypothetical facts, since, as he points out, these facts are the results of "combinations which can be made at will". ${ }^{69}$ They are therefore related to the preliminary theory of combinations. For instance, the theory can be applied to determine the "list of possible combinations" 70 which result from the throw of two dice. In the same way, "it can be applied to the form [...] of plurality decisions"71 by listing the several orders of preference concerning candidates or decisions. As to the relation between the classification of facts and the preliminary theory relative to general facts or general laws, Condorcet gives the example of the calculation of "birth and mortality tables" [p. 113]. Real facts which are considered as having a series of characteristics in common are effectively put together into the same group: "men and women are separated, either to find out how many individuals there are in each group, or to assess the mortality rate for each sex."72 That is how one can deduce "from observed facts either general facts or even more general laws" [p. 117]. In that specific case, "a table showing how many among a given number of males all born on the same day survive after the first year, after the second year, etc., displays a series of general facts, such as: in this country, half of all males perish before reaching ten years of age."73 Condorcet adds: "if I can represent this table by a formula, then it is a general law. It could be formulated thus: out of a given number of men of a certain age, an equal number die each year, or, in other words, the ratio of annual deaths to survivors increases arithmetically." 74

Once the facts have been determined, "there remains to determine their probability" [p. 112.], which is where the fourth preliminary theory of the Social Mathematic comes in. Thus, in the case of hypothetical facts one tries to ascertain the probability for each combination of dice (resulting from a throw, or the probability associated with the "accuracy of choice" 75 for each election procedure, that is to say the probabilistic threshold above which a proposition may be accepted as true. ${ }^{76}$ For real facts, one must subject to probability analysis, for instance, the general law according to which, in the case of a specific number of women of the same age, an equal number dies every year. The truth of the frequency proposition relies on the hypothesis that what has been happening in the past will continue to

\footnotetext{
${ }^{69}$ [des combinaisons faites à volonté], p. 112.

70 [liste des combinaisons possibles], p. 127.

71 [peut s'appliquer à la forme [...] des décisions rendues à la pluralité des voix], ibid.

72 [on sépare les hommes des femmes, soit pour connaître le nombre des uns et des autres, soit pour examiner l'ordre de mortalité particulier à chaque sexe], p. 113.

${ }^{73}$ [un tableau qui exprime pour un nombre d'hommes nés le même jour combien survivent après la première année, après la seconde, etc., présente une suite de faits généraux, tels que celui-ci: dans tels pays la moitié des hommes périt avant d'avoir atteint l'âge de dix ans], p. 114.

${ }^{74}$ [si je puis représenter ce même tableau par une formule, alors j'ai une loi générale. Telle serait celle-ci: sur un nombre donné d'hommes de tel âge, il en meurt chaque année un nombre égal, ou, ce qui revient au même, le rapport du nombre des morts pour chaque année à celui des survivants, croît suivant une progression arithmétique], ibid.

75 [la bonté du choix], p. 127.

${ }^{76}$ For Condorcet, this threshold has to be determined according to the seriousness of the decision to be taken, or of the importance of the position to fill. This is explained at length in the Essai sur l'application de l'analyse [1785].
} 
do so in the future. Therefore, by taking this hypothesis into account, one can estimate to what degree of probability a proposition is true. Condorcet describes this process in the "Fourth Part" [1786] of the Mémoire sur le calcul des probabilités. ${ }^{77}$

We have restored the processes by which facts are determined and then become the objects of a probability analysis: both these processes are shown in the left-hand column of the following table. The corresponding passage in the 1793 text appears in the right-hand column. The bracketed numbers refer to the preliminary mathematical theories, as numbered by Condorcet.

\begin{tabular}{|c|c|}
\hline Restored part of the table & 1793 Edition \\
\hline I. & I. \\
\hline DETERMINATION OF THE FACTS. & Determination of the facts. \\
\hline A. Enumeration of the facts. & 1. Observed facts. 2. Hypothetical facts. \\
\hline 1. Observed facts. & \\
\hline 2. Hypothetical facts. & 1. Enumeration of the facts. 2. Classification \\
\hline B. Classification of the facts (3) & of the facts. \\
\hline [and/or] & (3) Combinations (2). \\
\hline Combination of the facts (2). & Probability of the facts (4). \\
\hline [then] & \\
\hline Probability of the facts (4). & \\
\hline
\end{tabular}

Step 2. The appreciation of the facts

After the determination of the facts comes the "appreciation"78 of the facts, or their "evaluation," 79 which rests on the "theory of average values" 80 . However, and even though Condorcet never states this explicitly, one has reason to believe it is not necessary to use it systematically. If we are dealing with hypothetical facts such as those which occur during a deliberation or an election, evaluating means no more than counting the number of votes in favour of each proposition or candidate. ${ }^{81}$ In the same way, for the calculus of mortality, cases such as stillborn children excepted,

\footnotetext{
${ }^{77}$ BC, p. 428-429.

78 [appréciation], p. 116, 119.

${ }^{79}$ [évaluation], p. 112.

${ }^{80}$ [la théorie des valeurs moyennes], ibid.

${ }^{81}$ In the case of a contradiction between the majority choice and individual preference orders, Condorcet's solution to cases in which three proposals or three candidates are in competition - that is to say comparing "pairs" of results and choosing the one in favour of which the more votes were given- would not be a problem, since it would also amount to a simple count. However, in Borda's "method of marks", as it will later come to be called, in which a specific numerical weight is attached to the ranks of individual choices, there must necessarily be a deeper reflection on "values".
} 


\section{Condorcet's Social Mathematic - A Few Tables}

the appreciation of real facts is a trivial question, which amounts just to counting the number of deceased people. The method of average values is then unnecessary.

The question is not as simple when it comes to calculating morbidity: counting the number of victims of an illness is not enough, since the distinction between health and illness, and between different illnesses, etc., is not unequivocal. It is all the more complex when one is faced with "many facts of the same kind which produce different effects." 82 This happens, for instance, when one envisages economic choice in uncertain circumstances, a theme to which Condorcet came back several times in the $1780 \mathrm{~s} .{ }^{83}$ In those cases, the individual has to determine the mathematical expectation of the profit he is expecting, that is to say an average amount which guarantees high enough probabilities that he will not to be bankrupt after a few operations, that he will recoup his outlay, make a profit, and so on.

To sum up, the process of appreciating the facts is roughly similar to what we call today quantitative -as opposed to qualitative- variables (coded "yes"/"no", or "0"/"1"). Such an appreciation process, just like the determination of the facts, has to be submitted to the probability calculus. Indeed, substituting an average value for a set of particular values, introduces a bias which Condorcet believes to be theoretically possible to measure by means of the probability calculus. That is why, in our restored table [appendix 3], a "probability" is associated with "average values."

No such links are to be found in the original 1793 edition, because the phrase "average values" does not appear under the heading devoted to the "appreciation of the facts." The table below continues with the comparison, and brings to the fore the gross printing mistake in the first and all subsequent editions.

\begin{tabular}{|c|c|}
\hline Restored part of the table & 1793 Edition \\
\hline II. & 2. \\
APPRECIATION OF THE FACTS & Appreciation of the facts. \\
Formation \& use of average values (5) & \\
[then] & Formation \& use of the values. \\
Their probability (4). & $\begin{array}{l}\text { Averages. 5. } \\
\text { Their probability (4). }\end{array}$ \\
\hline
\end{tabular}

\section{Step 3. Results of the facts}

Condorcet does not give as many details on the third and last step relating to the treatment of facts. It is not detailed in the synoptic representation of the Social Mathematic. Within the framework of the analysis of various modes of election or deliberation, one can infer that it consists of fixing the

\footnotetext{
82 [un grand nombre de faits de la même nature dont il naît des effets différents], p. 115.

${ }^{83}$ On that point, see J. N. Rieucau [1998].
} 


\section{Condorcet's Social Mathematic - A Few Tables}

order of preference for the outcome of the vote, and then assessing the probability that this order of preference be conformable to the truth. That is precisely what Condorcet does in the Essai sur l'application de l'analyse [1785]. One must turn to a passage in the Rapport et projet de décret sur l'organisation générale de l'instruction publique [1792-1793] to find it applied to the estimation of the duration of life. Condorcet explains that after having classified and evaluated the facts relative to "the climate, the food, the general habits, the various occupations," 84 one will have to estimate the probability of "the consequences one can possibly draw from them," 85 that is to say the probability of their effects on the duration of human life. Such consequences derive from "the hypothesis that nature being subject to constant laws, in similar circumstances, future events will display the same results as past ones." 86 This can be seen as a probabilistic approach to the principle of causation. Therefore, as it is presented in the Tableau général, "in this case, observation reveals no more than the coexistence of the fact regarded as the cause and that regarded as the effect. There remains to be decided, by using the calculus of probabilities, to what extent this coexistence must be regarded as the result of a constant law and if the effect can be attributed to its supposed cause, or due to chance, that is to say to an unknown cause." 87

We have already seen that the faultier and faultier transcriptions of the table affect specifically the third process, to which the facts are submitted, directly related as it is to the two-dimensional representation of the Tableau général. We shall not come back to it.

An overall comparison of the draft manuscript of Condorcet's table, our restored version of the table and the table as it is published in the various editions, reveals the number of editorial mistakes which have eventually distorted the "method of the science" and its relation to the preliminary theories. This comparison is significant. As early as the first edition, faults in the printed text are obvious, even taking into account the fact that the quality of papers published during the revolutionary period was poor, and steadily deteriorating. ${ }^{88}$ Condorcet's control of the text was prematurely interrupted. Therefore one can put forward the following scenario, even though it cannot remain otherwise than hypothetical. The manuscript we possess could be the initial outline in which Condorcet described his work. Starting from it, he would have written, in almost one go, a draft for the Tableau général, as well as a more detailed but still imperfect version of the synoptic table, some features of which appear in the

\footnotetext{
${ }^{84}$ [le climat, la nourriture, les habitudes générales, les professions diverses], OC, vol. VII, p. 557.

${ }^{85}$ [conséquences qu'il est possible d'en tirer], ibid., p. 558.

86 [sur l'hypothèse que la nature étant assujettie à des lois constantes, les événements futurs présenteront, dans des circonstances semblables, les mêmes résultats que les événements passés], ibid.

${ }^{87}$ [L'observation ne peut faire connaître ici que la co-existence entre le fait regardé comme cause, à [= avec] celui qu'on regarde comme l'effet. Il reste à déterminer par le calcul des probabilités, si l'on doit, ou non, regarder cette co-existence comme résultante d'une loi constante, si l'effet doit être attribué à la cause qu'on lui suppose, ou au hasard, c'est-à-dire à une cause inconnue.], p. 122. By putting forward a probabilistic evaluation, Condorcet attempts, in a way, to "rescue" the causation principle from Hume's devastating theory. For a more detailed study, see J. N. Rieucau [2003]. Philosophical and mathematical reflection on the relations between "causes" and "effects" was a central question for Condorcet and his circle, as it had been for d'Alembert and Laplace.

${ }^{88}$ On that point see C. Bellanger \& al. [1969], p. 435.
} 
printed text. ${ }^{89}$ Almost a clandestine already, Condorcet would not have been able to reread and correct the prints, even once. They would have been delivered to the printer in their original state, unless a copyist had produced a fair copy unrevised by Condorcet.

Whatever the stage up to which Condorcet was in charge of his text, we must insist that the printed version of his synoptic table was extremely misleading. Only a restored version of the table, based on the objects as well as on the method (and the preliminary theories) of the Social Mathematic can allow a faithful and accurate understanding of his project. In this way, as we shall presently see, the restored version can allow one to demonstrate the precise place which the Social Mathematic occupies within the entire table of human knowledge, according to Condorcet.

\section{THE SOCIAL MATHEMATIC IN THE FIELD OF HUMAN KNOWLEDGE}

The separation between the Social Mathematic and the other branches of human knowledge and, more broadly, its place within the classification of sciences, should not lead us to believe that it constitutes an independent field for Condorcet. In the wake of the Encyclopédie - meaning literally "the chain of knowledge" according to Diderot [1775, p. 635] - Condorcet looks for continuity in the field of epistemology. As he explains in the Tableau général, "the weakness of the human mind, the necessity to save time and effort forces us to divide the sciences, to circumscribe and to classify them." 90 Condorcet insists that the last operations can be made "either according to the objects considered, or according to the methods employed."91 Therefore, one must distinguish between an "objective" and a "methodological" criterion to understand the specific relations the Social Mathematic bears to other fields of knowledge. This study will also involve preliminary theories [3.1]. What is more, the distinction is also useful in explaining, from a broader point of view, the place Condorcet gives to the Social Mathematic within the complete table of human knowledge [3.2].

\footnotetext{
${ }^{89}$ One of the features is the order in which the objects devoted to "things" and to "men" are presented. In the surviving mss folio [MS 885 (II), f. $3=208$ ], one notices that after a few hesitations, Condorcet chose to call these objects the first and the second object of the Social Mathematic. In the printed text, the order is reversed [p. 119, 120, $121 \mathrm{ff}$.] which hints towards the existence of a second manuscript version. One can also mention the way in which Condorcet entitles the two subheadings of the title devoted to "men": in our manuscript, man is seen either as a "physical" or a "moral" being, which differs in its form from the printed text the phrases are "Man as an individual" and "the operations of the human mind", or "Intellectual operations." [l'homme individu / les opérations de l'esprit humain / les opérations intellectuelles], p. 106, 110-111, 119, 121, 124, 126-127.

${ }^{90}$ [c'est la faiblesse de l'esprit humain, c'est la nécessité de ménager le temps et les forces, qui nous oblige à diviser les sciences, à les circonscrire, à les classer], p. 183. See also: "the sciences are linked by a chain by which every one of them is attached to all the others, and where they meet, they come in support of each other" [les sciences se tiennent par une chaine qui unit chacune d'elles à toutes les autres, et au point où elles se rapprochent, elles se prêtent des secours mutuels], Discours à l'Académie française [1784], OC, vol. I, p. 439.

${ }^{91}$ [tantôt d'après les objets qu'elles considèrent, tantôt d'après les méthodes qu'elles emploient], p. 183.
} 


\subsection{Social Mathematic, pure mathematics, physical sciences and social sciences}

Because the framework of the Tableau général is built around two entries, its objects -men, things, and men and things together- and its method - the use of mathematics, and of probability calculus especially- Condorcet could choose between two titles for his project. By choosing the phrases "social sathematic" (and not "mathematical social science") and "application of the calculus to political and moral sciences" (and not "calculated political and moral sciences"), Condorcet lays the emphasis, from a semantic point of view, on the method rather than on the objects of the topic he means to publicise. Accordingly, after having mentioned that the separation and the classification of knowledge can be effected "according to the objects considered" or "according to the methods employed," Condorcet stresses that the Tableau général deals with the "latter division"92. Starting from that "methodological" criterion, he draws the dividing lines between the Social Mathematic and other fields of human knowledge: pure mathematics, physical sciences, and social sciences.

Of course, the Social Mathematic falls short of the entire field of science. As we have seen, it must be "preceded by five mathematical theories", which, he adds, "can be developed independently of all applications." 93 Condorcet's works indeed stress enough that there is a field of knowledge specifically devoted to pure mathematics $!^{94}$ Besides, the preliminary theories being general, they can of course be of use, for Condorcet and for other scientists of the time, in other fields such as those of the Social Mathematic, first in astronomy and also in the physical sciences at large. The process of deducing laws or general facts, together with the theory of combinations, are two methods which should, according to Condorcet, be employed for all kinds of facts, that is to say not only for "moral" objects - such as those which relate to human mortality-, but also for "physical" ones -including those which relate to plants and minerals. ${ }^{95}$ In the same way, the preliminary theory of average values is not limited to the "specific application in calculus" of the Social Mathematic, because "in all physicomathematical sciences it is useful to have average values of observations or results of experiments." 96 Lastly, to the extent that "after having considered the facts, the average values or the results, there remains to deduce their probability," the preliminary theory of the calculus of probabilities is, Condorcet insists, "both a part of the science under examination and one of the foundation stones of all others," 97 including the physical sciences.

With its preliminary theories, the method of the Social Mathematic bridges the gap between its branch and that of the mathematical and physical sciences, while acknowledging that they both constitute distinct fields of human knowledge.

\footnotetext{
92 Ibid.

93 [être précédée par cinq théories mathématiques, qui peuvent être développées indépendamment de toute application], p. 116.

94 The relevant works are listed in C. Gilain \& C. Houzel [1988].

${ }^{95}$ See especially Élémens du calcul des probabilités, p. 506 ff.

96 [application particulière du calcul... dans toutes les sciences physico-mathématiques, il est également utile d'avoir des valeurs moyennes des observations ou du résultat d'expériences], p. 116.

${ }^{97}$ See supra, n. 25.
} 
The links between the Social Mathematic and the social sciences seem at first sight more complex. One can of course guess that they are more closely connected, since the Social Mathematic is applied to social sciences. However, does the latter include the former? Condorcet does not deal with this question directly in the Tableau général, which is not surprising since it is probably unfinished. However, his demonstration can easily be reconstructed. In that respect, we must study how the encyclopédiste envisages the relations between, on the one hand, the Social Mathematic as applied to "things" - an aspect which is quite well developed in the unfinished Tableau général- and, on the other hand, political economy as a branch of the social sciences.

Firstly, Condorcet declares that this "second part of the table listing the objects to which calculus can be applied", that is to say the Social Mathematic devoted to "things", "appears to embrace virtually the whole of political economy, as it must since political economy considers things simply in relation to their value." But he adds immediately that "however these two sciences must not be confused."98 Indeed, the Social Mathematic is only "devoted to the analysis of ideas, or facts" which political economy has provided, "to the extent necessary to ensure that the calculus is based on solid foundations." 99 The link remains tight, because "the social mathematic would only teach how to calculate abstractions, if it did not borrow from political economy the data it employs and if the latter did not indicate the important questions to solve." 100 The objects are the same ("things"), but their methods are different and complementary: "though political economy employs observation and reason, yet the need for calculus can be felt at every moment." 101 The distinction between these two sciences is only possible by taking their methods into account, and not their object, as to which they are one and the same. ${ }^{102}$

More generally, the links between the Social Mathematic and the social sciences have to be considered in the same way, that is to say by specifying whether the "objects" or the "method" are the focus of the enquiry. If the "objects" are, then there is only one branch of knowledge: the Social Mathematic and the social sciences both have for their objects men, things, and men and things together. However, starting from their "methods", they are complementary, and not identical, which is what Condorcet shows implicitly by choosing the name "social mathematic" and not "mathematical social science". Grounded on observation and reason, the social sciences present the Social Mathematic

\footnotetext{
98 [cette seconde portion du tableau des objets auxquels le calcul peut s'appliquer paraît embrasser l'économie politique presque entière; et cela doit être, puisque l'économie politique ne considère les choses que relativement à leur valeur [...] cependant ces deux sciences ne doivent pas être confondues.], p. 182.

99 [s'occuper de l'analyse des idées, ou des faits... qu'autant qu'il le faut pour s'assurer d'appuyer le calcul sur des bases solides.], p. 183.

${ }^{100}$ [la mathématique sociale n'apprendra[it] à calculer que des abstractions, si elle n'empruntait de l'économie politique les données qu'elle doit employer, si celle-ci ne lui indiquait les questions qu'il est important de résoudre.], p. 184.

${ }^{101}$ [quoique l'économie politique emploie l'observation et le raisonnement, cependant on y éprouve à chaque instant le besoin du calcul.], ibid.

${ }^{102}$ G. G. Granger [1956, p. 156-157] has also studied the links between the Social Mathematic and political economy. However, he does not distinguish between two approaches (the "objective" and the "methodological" ones) which are necessary to understand this question. His demonstration is therefore unclear.
} 
with specific data and problems. In turn, the Social Mathematic throws light on the social sciences by calculus.

The distinction between an "objective" and a "methodological" criterion allows one to understand the relations between the Social Mathematic and the other fields of knowledge. It is also central to the broader issue of the place of that specific branch within the classification of human knowledge as Condorcet understands it. This question, as we shall see, must be studied as a "dynamic" phenomenon, since the Social Mathematic represents, for Condorcet, a historical moment in the evolution of the progress of the human mind.

\subsection{Social Mathematic and the sketch (of the progress) of the human mind}

For Condorcet, the Social Mathematic is a new branch in the history of human knowledge. He mentions that "in Holland the celebrated Johan de Witt, a disciple of Descartes, and in England Sir William Petty took the first steps towards this science in the last century." ${ }^{103}$ Other passages allow us to understand more clearly the double genealogy alluded to here. In fact, Condorcet did not hold Petty's work in high esteem. As he wrote in a manuscript around 1780, his "Essai d'arithmétique politique"104 "did not deserve" the name much, since its only aim was to "prove the superiority of England over France." ${ }^{105}$ In that respect, when Condorcet coined the expression "social mathematic", he probably meant it to replace the traditional phrase "political arithmetic", which he considered too narrow and too much associated with a writer whose works belonged at best to the prehistoric times of that science. ${ }^{106}$ His judgment on De Witt was far different. The latter was indeed the first writer who "thought of applying the calculus of probabilities"107 to the field of political arithmetic. By so doing, De Witt has initiated a modern, probabilistic approach to this branch of knowledge.

The birth of the Social Mathematic therefore represents, for Condorcet, a recent event in the history of the sciences. In that respect, the first paragraphs of the Tableau général insert it within another sketch, that of the progress of human knowledge:

\footnotetext{
"When the sciences are in their infancy, an individual can study them at the same time; but they remain isolated [...]. On the contrary, when, by their advancement, they force the scientists to divide its various branches between themselves, lines of communication form between them, and the way one science can be applied to another often becomes its most useful or its most illuminating function.
}

\footnotetext{
103 [en Hollande, le célèbre Jean de Witt, disciple de Descartes, et en Angleterre, le chevalier Petty, donnèrent les premiers essais de cette science dans le siècle dernier], p. 106.

104 The work quoted by Condorcet is more precisely a 1699 edition, published in London, with a "preface" in French, entitled "Several Essays in Political Arithmetic".

${ }^{105}$ Réflexions sur l'arithmétique politique, BC, p. 336-337, p. 537. See also Lettre à Garat [around 1784-1785], BC, p. 541.

${ }^{106}$ For more details on the reasons why Condorcet coined the phrase "Social Mathematic", see J. N. Rieucau [2005 a].

${ }^{107}$ Lettre à Garat [around 1784-1785], BC, p. 541. See also Notes sur Voltaire [1784-1789, OC, vol. IV, p. 634-635] and Esquisse d'un Tableau historique des progrès de l'esprit humain [1793-1794], p. 380.
} 


\section{Condorcet's Social Mathematic - A Few Tables}

Two conditions must be met before one science can be applied to another, firstly each of the branches must have reached a certain development, but also there must be sufficient general familiarity with them to ensure that there are men who know them both, and can pursue both faithfully and accurately.

The application of calculus to moral and political sciences could therefore only appear once mathematics had been studied successfully in nations where freedom was accompanied by peace and supported by enlightenment." 108

Therefore, if we direct our enquiries to the place occupied by the Social Mathematic within the classification of the sciences, we can guess that it only appeared quite recently according to Condorcet. That being admitted, the way in which the Social Mathematic appears within the nomenclature of human knowledge depends also on the way that nomenclature is constructed. In one of the important vocabulary notes to the Tableau historique, Condorcet writes that the criteria can depend on either the "method" employed by the sciences, the "objects" they deal with, or the "faculties they exercise". ${ }^{109}$

As Condorcet points out, the last of these criteria, which distributes sciences according to the faculty they exercise (memory, reason or imagination) was chosen by Bacon in The General Distribution of Human Knowledge [1623] and was taken up by Diderot and d'Alembert, in the early $1750 \mathrm{~s}$, in the first pages of the Encyclopédie. ${ }^{110}$ Condorcet rejects this method of classification, in which the Social Mathematic would have to be placed together with the sciences which depend on reason, in the branch of "mixed" mathematics. He argues that there is no field of knowledge, including mathematics, in which all three faculties do not play a role. ${ }^{11}$ Starting from those categories leads to an arbitrary classification.

It remains to be seen what judgement Condorcet passes on the classification founded on "methodological" or "objective " criteria. His opinion varies according to the texts. In the Rapport et projet de décret [1792-1793], Condorcet favours the first of these criteria in classifying the subjects in his instruction system: "we believed we had to distribute the sciences according to the methods they

\footnotetext{
108 [Dans les premiers âges des sciences, un seul homme les cultive à la fois; mais elles restent isolées [...]. Au contraire, lorsque leurs progrès forcent les savants à s'en partager les diverses branches, on voit s'établir entre elles des lignes de communication, et l'application d'une science à une autre en devient souvent la partie la plus utile ou la plus brillante.

Cette application exige non seulement que chacune des deux sciences ait atteint une certaine étendue, mais que chacune aussi soit assez répandue pour qu'il se trouve des hommes qui, les possédant toutes deux à la fois, puissent en parcourir la double carrière d'un pas égal et sûr.

L'application du calcul aux sciences morales et politiques n'a donc pu naître qu'à l'époque où les mathématiques ont été cultivées avec succès chez des peuples dont la liberté ait [= a] eu la tranquillité pour compagne et les lumières pour appui.], p. 105.

109 [la méthode... les objets... ou les facultés qu'elles exercent.], Sur les sens des mots sciences et art - Sur les classifications des sciences et des arts, p. 766.

${ }^{110}$ D’Alembert, "Discours préliminaire" [1751 a], Encyclopédie, vol. 1, p. xiv-xjx; Diderot, "Explication détaillée du système des connaissances humaines" [1751 a], Encyclopédie, vol. 1, p. xlvij-lj; Diderot, " Système figuré des connaissances humaines" [1751 b], Encyclopédie, vol. 1, s. p.

111 "There is no science in which understanding, imagination and memory are not employed, none in which one further step can be taken without these three faculties being used. [...] Mathematics are placed among the sciences belonging to the understanding, but if the word "imagination" is understood in a philosophical sense, one must confess that without possessing this faculty in the highest degree, neither Archimedes nor Euler could have produced their works." Sur les sens des mots sciences et art - Sur les classifications des sciences et des arts, p. 767. See also: "How can you attribute such part of human knowledge to memory, to imagination, to reason, if when, for instance, you ask a child to demonstrate a geometrical proposition on a board, he cannot do so without using at once his memory, his imagination and his reason?" Rapport et projet de décret sur l'organisation générale de l'instruction publique [1792-1793], OC, vol. VII, p. 466
} 


\title{
Condorcet's Social Mathematic - A Few Tables
}

employ, and consequently, according to the total knowledge which is the most common among educated men, or which it is the easiest for them to complete." ${ }^{112}$ A few lines later, he underlines that the "didactic" dimension is essential to him:

\begin{abstract}
"The same object, according to the manner in which it is considered, belongs to absolutely different sciences. Sciences thus classified require qualities of mind which one person seldom possesses at once; it would have been very difficult to find, and maybe even to train, men who could yield to these divisions of teaching. Similar sciences would not correspond to similar occupations, their parts would not appeal equally to all minds, and these divisions would have tired students and masters." 113
\end{abstract}

One can suggest a second reason: classifying sciences according to their "method" allows him to highlight and to promote the teaching of calculus applied to political and moral sciences, by giving these sciences a specific status (which they would not have had in a classification based on "objects", in which they would have been called something like "calculated political and moral sciences", and have constituted only a subheading in the larger category of "political and moral sciences"). Besides, in a note stretching over several pages, Condorcet underlines "the utility of teaching on its own a wide, important and almost new science," that is to say the application of calculus to political and moral sciences. ${ }^{114}$ This is also what he did in the following year, by publishing the Tableau général in a Journal devoted to social instruction. ${ }^{115}$ Therefore, the phrase "social mathematic" (as opposed to "mathematical social sciences") comes to the fore, because it corresponds to a "methodological" classification of sciences.

However, shortly afterwards, in a manuscript text Sur les sens des mots sciences et art [17931794], Condorcet rejects the above classification. He explains the reasons for it: "if we choose as a foundation the methods they [the sciences] employ [...] we shall soon be stopped by the inconvenience of separating truths which are constantly investigated into by the same men and which are naturally connected. We would have to separate astronomy based on observation from astronomy based on calculus." ${ }^{116}$ At that stage, Condorcet undertook a classification of human knowledge resting on the division of the psychological and the physical fields. ${ }^{117}$ There is no mention of the Social Mathematic or of anything similar, since the "methodological" classification is not adopted. However, Condorcet's thought has not changed. Although he presents his classification as "objective," he underlines the importance of applying mathematics to the entire field of human knowledge, in order to gain "precision and certainty."118

\footnotetext{
112 Ibid.

${ }^{113}$ Ibid., p. 467.

${ }^{114}$ Ibid., p. 564.

115 The didactic aim of the paper is stressed at length in the "Prospectus" [late May 1775].

116 p. 768.

${ }^{117}$ Ibid. This is commented in ibid., p. 761-764.

${ }^{118}$ Ibid., p. 772.
} 


\section{Condorcet's Social Mathematic - A Few Tables}

Besides, several instances in the Tableau historique show that the "didactic" purpose, which was prevalent in his writings devoted to instruction and which had led him to reject a classification based on method, has become less important. Indeed, he is writing an "historical sketch" of the "progress of human knowledge", the scope of which increases gradually, together with the ability to teach it. In the "Tenth Stage" of the Esquisse, devoted to the "future progress of the human mind," Condorcet indeed considers the possibility that the intellectual faculties of the human mind could be saturated by the extension of the fields of investigation: "one could believe that, man being only able to understand a fragment of the objects which the nature of his intelligence allows him to reach, must eventually reach a point when all his forces being absorbed by the number and the complexity of what he knows already, any further progress would be impossible." ${ }^{19}$ Condorcet manages to dismiss the hypothesis according to which the faculties of man "as a human mind" would be limited, with the help in particular of the use of mathematics, and more specifically of the third preliminary theory of the Social Mathematic: "as facts become more numerous men learn how to classify them and to reduce them to more general ones." 120 Then, when he mentions the "prejudiced view"121 according to which some sciences would be "nearing completion,"122 he stresses: "we shall explain all the profit a more general and philosophical application of the sciences of calculus to the entire field of human knowledge will add to the whole system of knowledge, in extent, precision and unity."123 A few pages later, he emphasises that in the field of social science, such application "promises even further progress [in that field] since it is at the same time the only means to give almost mathematical precision to its results, or to appreciate its degree of certainty or verisimilitude." ${ }^{124}$ Indeed, "without applying calculus, it would often be impossible to choose with any certainty [between] two combinations formed to reach the same goal, when their advantages are not strikingly disproportionate." 125

The central place attributed to the Social Mathematic can be see even further: one can consider that the Tableau historique of 1793-1794 itself derives from it in several respects. Thus, the forecasts presented by Condorcet in his "Tenth Stage" bearing on "the future progress of the human mind" can be interpreted in the light of his probability-based theory of knowledge. This theory, which is central to the understanding of "man as mind" within the Social Mathematic, aims at deducting probable inferences concerning the future from past experience. ${ }^{126}$ In the same way, it must be noted that the classification methods which are used especially in the step of the Social Mathematic devoted to "the determination of the facts" are presented by Condorcet as constitutive of the "art of drawing [...] historical

\footnotetext{
${ }^{119}$ Esquisse, p. 441-442.

${ }^{120}$ Ibid, p. 442.

${ }^{121}$ Ibid., p. 443.

122 Ibid.

${ }^{123}$ Ibid.

${ }^{124}$ Ibid., p. 447.

125 Ibid.

${ }^{126}$ For further details on the link between Condorcet's theory of knowledge and his forecasts into the future progress of the human mind, see L. Loty [1988].
} 
tables" [p. 126]. The way in which the Table de référence accompanying the Tableau historique is organised corresponds in minute details to one of the arrangement systems envisaged by Condorcet ${ }^{127}$.

The Social Mathematic is therefore present in Condorcet's last major work, the Tableau historique des progrès de l'esprit humain, it influences the contents of the work, but also, at least in part, the method from which it was constructed.

\section{Conclusion}

The seeds of Condorcet's plan of applying calculus to political and moral sciences were already present in the early 1770s, when Condorcet located the "science of moral or political relations" within the branch of "physical mathematics." ${ }^{128}$ He developed it in various ways throughout the 1780 s, most famously with his work on elections. In that respect, although the Tableau général is indeed a blueprint for future work, it also constitutes a methodological synthesis of earlier researches. But its most specific features lie elsewhere. It is at the same time a mature text, and, mostly because of the political circumstances in which it was written, quite a confused one, whose structure could have been improved. We have attempted to give the reader keys, especially by restoring the two dimensions that Condorcet wished it to be presented in, and this has allowed us to place the Social Mathematic within the table of human knowledge. Retrospectively, one can imagine how much care Condorcet would have given to correcting and completing the Tableau général had he had sufficient time for it. Under threat of impending banishment, at the climax of political instability, Condorcet chose to write quite an abstract text, almost the last which bore his signature. ${ }^{129}$ In no case can it be considered as a contingent work which he would have "taken lightly". Why did he decide to write it at that specific time? By presenting what he believed to be the true science of public happiness, his goal might have been "to rise above political debates", as M. Dorigny [1981] has hinted. One can also suggest that Condorcet, who was already living half-clandestinely, meant to leave behind a legacy, with the intention of promoting a subject of enquiry which, as he wrote a few months later, "despite the successful attempts of some mathematicians, remains, as it were, in its early stages and [...] [which] must open for the next generations a truly infinite source of enlightenment." ${ }^{130}$ One can guess that Condorcet considered himself as one of these "mathematicians".

\footnotetext{
127 This point is explained in Condorcet, Tableau historique des progrès de l'esprit humain (1772-1794), p. 1058-1059.

${ }^{128}$ Ébauche de division des mathématiques, BC, p. 237.

${ }^{129}$ Excepting the Lettre de Condorcet à la Convention Nationale [early August 1793], OC, vol. XII, p. 682-684.

${ }^{130}$ Esquisse, p. 448.
} 


\section{ABBREVIATIONS USED IN THE TEXT AND THE BIOBLIOGRAPHY}

- "OC": EEuvres de Condorcet [1847-1849], F. Arago and A. O'Connor (eds.), Paris, Firmin-Didot, 12 vols. Reprint: Stuttgart-Bad Cannstatt, Friedrich Frommann Verlag (Günther Holzboog): 1968.

- 'BC": Condorcet. Arithmétique politique. Textes rares ou inédits [1767-1789], B. Bru \& P. Crépel (eds.), Paris, INED, 1994. This abbreviation is only used to refer to Condorcet's texts, and not to the studies by B. Bru \& P. Crépel contained in the same volume.

- "TH" : Condorcet, Tableau historique des progrès de l'esprit humain (1772-1794), Paris, INED, 2004.

- "MS": Manuscripts, Bibliothèque de l'Institut de France.

- "n. a. fr." : Manuscripts ("Nouvelles acquisitions françaises"), Bibliothèque Nationale de France.

\section{CONDORCET}

TABLEAU GENERAL DE LA SCIENCE QUI A POUR OBJET L'APPLICATION DU CALCUL AUX SCIENCES POLITIQUES ET MORALES: EDITIONS AND REPRINTS

- Journal d’instruction sociale [June 22/29, 1793 \& July 6, 1793], n4, p. 105-128; n 6, p. 166-184. Reprint: Paris, EDHIS, 1981.

- Euvres complètes de Condorcet [1804], S. de Grouchy, A. A. Barbier, P. G. Cabanis, D. J. Garat (eds.), Paris, Heinrichs, vol. 21, p. 235-286.

- Élémens du calcul des probabilités et son application aux jeux de hasard, à la loterie et aux jugemens des hommes [1805], Fayolle (ed.), Paris, Royez, p. 171-210.

- CEuvres de Condorcet [1847-1849]: OC, vol. I, p. 539-573.

- $\quad$ Rashed R. [1974], Condorcet, Mathématique et société, Paris, Hermann, p. 196-216

- Condorcet. Sur les élections et autres textes [1986], O. de Bernon (ed.), Paris, Fayard, p. 597-623.

- Condorcet - Foundations of Social Choice and Political Theory [1994], I. McLean \& F. Hewitt (ed. \& translation), Edward Elgar, p. 93-110.

- Thuillier G. [1997], Le premier actuaire de France: Duvillard (1755-1832), Paris, Comité d'histoire de la Sécurité sociale, p. 465-486

\section{OTHER TEXTS}

- « [Division de l'analyse]» [w. d.], in E. Brian [1994], p. 219.

- « [Ébauche de division des mathématiques]» [around 1770], [Deux manuscrits inédits sur l'analyse], BC, $\mathrm{p}$. 240-246.

- " « Arithmétique politique », [Projet d’Abrégé de l’Encyclopédie], 1772, BC, p. 303.

- Éloge de Jussieu [1778], OC, vol. II, p. 238-270.

- «Essai d'une méthode pour trouver les loix des phénomènes d'après les observations » [1775-1776], in C. Bossut [1777], Nouvelles expérience sur la résistance des fluides, Paris, Jombert, p. 195-230.

- Réflexions sur l'arithmétique politique [around 1780], BC, p. 336-338.

- Principes pour calculer les loteries partie en rentes perpétuelles, partie en rentes viagères [1780's], BC, $\mathrm{p}$. 589-594.

- Précisions sur le programme du prix relatif aux assurances maritimes [around 1783], BC, p. 467-469.

- " Mémoire sur le calcul des probabilités », in six parts, Mémoires de l’Académie royale des sciences (Paris) year 1781 [1784], p. 707-728; year 1782 [1785], p. 674-691; year 1783 [1786], p. 539-559; year 1784 [1787], p. 454-468; BC, p. 385-448.

- $\quad$ [Manuscrit sur les loteries] [1784?], BC, p. 553-556.

- «Arithmétique politique » [1784], Encyclopédie méthodique, BC, p. 483-485.

- " «Assurances maritimes » [1784], Encyclopédie méthodique, BC, p. 485-494.

- Discours à l'Académie française [1784], OC, vol. I, p. 435-445. 
Condorcet's Social Mathematic - A Few Tables

- Lettre à Duvillard [1790?], in G. Thuillier [1997], p. 449-451.

- Lettre à Garat [around 1784-1785], BC, p. 541-542.

- $\quad$ Notes sur Voltaire [1784-1789], OC, vol. IV, p. 317-635.

- Essai sur l'application de l'analyse à la probabilité des décisions rendues à la pluralité des voix [1785], Paris, Imprimerie royale.

- «Probabilité » [1785], vol. II, p. 649-663; BC, p. 494-515.

- Vie de M. Turgot [1786], OC, vol. V, p. 1-233.

- Elémens du calcul des probabilités et son application aux jeux de hasard, à la loterie et aux jugemens des hommes [1786-1787], Paris, Fayolle, 1805; in Condorcet. Sur les élections et autres textes [1986], O. de Bernon (éd.), Paris, Fayard, p. 483-596.

- $\quad$ [Fragments sur les rentes viagères] [1786-1787], BC, p. 615-617.

- Application du calcul des probabilités aux questions où la probabilité est indéterminée [1786-1787], BC, p. 618-625.

- $\quad$ Lettre de Condorcet et de Laplace au baron de Breteuil [July 12, 1787], BC, p. 642-644

- Essai sur la constitution et les fonctions des assemblées provinciales [1788], OC, vol. VIII, p.115-659.

- $\quad$ Rapport de Condorcet et de Laplace sur le projet d'assurance-vie de Beaufleuri [1790], BC, p. 644-645.

- Sur les caisses d'accumulation [1790], OC, vol. XI, p. 387-403.

- Mémoires sur la fixation de l'impôt [1790], OC, vol. XI, p. 405-470.

- $\quad$ Mémoires sur les monnaies [1790], OC, vol. XI, p. 581-673.

- Rapport et projet de décret sur l'organisation générale de l'instruction publique [1792-1793], OC, vol. VII, p. 449-573.

- «Prospectus » [late May 1793], Journal d'instruction sociale, p. 1-11.

- «Que toutes les classes de la société n'ont qu'un même intérêt» [June 8, 1793], Journal d'instruction sociale, $\mathrm{n}^{\circ} 2$, p. 49-55.

- $\quad$ [Tableau synoptique de la Mathématique sociale] [1793], MS 885 (II), f. 3 = 208.

- $\quad$ Lettre de Condorcet à la Convention nationale [early August 1793], OC, vol. XII, p. 682684.

- $\quad$ [Plan de 1793]», TH, p. 1054.

- «Esquisse [or « Prospectus »] d'un Tableau historique des progrès de l'esprit humain » [1793-1794], TH, p. 233-459.

- $\quad$ «xemple des méthodes techniques » [1793-1794], TH, p. 1033-1048.

- « Sur les sens des mots sciences et art - Sur les classifications des sciences et des arts » [1793-1794], TH, p. 765-773.

- «Table de référence » [1793-1794], TH, p. 1060-1062.

\section{OTHER AUTHORS}

- ALEMBERT J. le R. (d') [1751 a], «Discours préliminaire », in D. Diderot \& J. le R. d'Alembert [17511765], vol. I, vol. I, p. j-xlv.

- ALEMBERT J. le R. (d') [1751 b], «Arrérages », in D. Diderot \& J. le R. d'Alembert [1751-1765], vol. I, vol. I, p. 705-707.

- ALENGRY F. [1904], Condorcet, Guide de la Révolution française, Geneva, Slatkine Reprints, 1971.

- $\quad$ ARROW K. J. [1951, 1963], Social choice and individual values, New York, 1951 (1 ${ }^{\text {st }}$ ed.), 1963 (2nd ed.), translation of Choix collectifs et préférences individuelles, Paris, Calmann-Lévy, 1974.

- BACON F. [1623], "The General Distribution of Human Knowledge », Of the Proficience and Advancement of Learning, in Works of Francis Bacon, London, 1778, vol. I, p. 42.

- BADINTER E. \& R. [1988], Condorcet. Un intellectuel en politique, Fayard.

- BAKER K. M., « The Early History of the Term "Social Science" » [1964], Annals of Science, vol. $\mathrm{XX}, \mathrm{n}^{\circ}$ 3, p. 211-226.

- BAKER K. M. [1975], Condorcet. From Natural Philosophy to Social Mathematics, Chicago, University of Chicago Press; translated by M. Nobile: Condorcet, raison et politique, Paris, Hermann, 1988.

- BELLANGER C. \& al. (eds.) [1969], Histoire générale de la presse française, Tome 1: Des origines à 1814, Paris, PUF. 
- BERNOULLI Jean III [1777], «Milieu», in D. Diderot and J. le R. d'Alembert, Supplément de l'Encyclopédie ou Dictionnaire raisonné des sciences, des arts et des métiers, vol. III, p. 935-939.

- BIONDI Y. [2003], «Les "Recherches sur les rentes" de Duvillard et le taux interne de rentabilité », Revue d'histoire des mathématiques, $\mathrm{n}^{\circ}$ 9, p. 81-130.

- BLACK D. [1958], The theory of committees and elections, Cambridge University Press, 1958.

- BRIAN E. [1994], La mesure de l'État - Administrateurs et géomètres au XVIII siècle, Paris, Albin Michel.

- BRIAN E. [1997], «Compte rendu de "Table ronde: Editer Condorcet aujourd'hui"», in A. M. Chouillet \& P. Crépel, Condorcet-Homme des Lumières et de la Révolution, Fontenay/Saint-Cloud, ENS Éditions, p. 273-283.

- BRU B. \& CREPEL P. [1994], Condorcet. Arithmétique politique. Textes rares ou inédits (1767-1789), Paris, INED.

- CAHEN L. [1904], Condorcet et la Révolution française, 1904; Geneva, Slatkine Reprints.

- CREPEL P. [1988], "Condorcet, la théorie des probabilités et les calculs financiers », in R. Rashed (ed.), Sciences à l'époque de la Révolution française, Paris, Blanchard, p. 267-325.

- CREPEL P. [1990], «Les calculs économiques et financiers de Condorcet pendant la Révolution », in G. Faccarello \& P. Steiner (eds), La pensée économique pendant la Révolution Française, P. U. G., p. 339-350.

- CREPEL P. \& GILAIN C. (eds) [1988], Condorcet - Mathématicien, économiste, philosophe, homme politique, Actes du Colloque International Condorcet, Paris, Minerve, 1989.

- DELSAUX H. [1931], Condorcet journaliste (1790-1794), Paris, Honoré Champion.

- DIDEROT D. \& ALEMBERT J. le R. (d') (eds.) [1751-1765], Encyclopédie ou Dictionnaire raisonné des sciences, des arts et des métiers , New York, Reader Microprint Corporation, 1969, 5 vol, 35 vols.

- DIDEROT D. [1751 a], «Explication détaillée du système des connaissances humaines » - appendix to J. le R. d'Alembert [1751 a], Encyclopédie, vol. I, vol. I, p. xlvij-lj.

- DIDEROT D. [1751 b], «Système figuré des connaissances humaines », in D. Diderot \& J. le R. d'Alembert [1751-1765], vol. I, vol. I, s. p.

- DIDEROT D. [1755], «Encyclopédie », in D. Diderot \& J. le R. d'Alembert [1751-1765], vol. I, vol. 5, p. 635-648.

- DORIGNY M. [1981], « Présentation », Journal d'instruction sociale, Paris, EDHIS.

- DORIGNY M. [1989], « Journal d'instruction sociale », Dictionnaire historique de la Révolution française, Paris, PUF, p. 604.

- DUVILLARD DE DURAND E. E. [1787], Recherches sur les rentes, les emprunts et les remboursemens.

- DUVILLARD DE DURAND E. E. [around 1813-1814], « Souvenirs », G. Thuillier [1997], p. 29-43.

- DUVILLARD DE DURAND E. E. [1816], «Première esquisse du Tableau général de la mathématique sociale », in G. Thuillier [1997], p. 309-387.

- FAYOLLE F. J. M. [1805], « Notice sur M. de Condorcet», Élémens du calcul des probabilités et son application aux jeux de hasard, à la loterie et aux jugemens des hommes, Fayolle (ed.), Paris, Royez, p. IXII.

- GALUZZI M. [1995], «Lagrange's essay "Recherches sur la manière de former des tables des planètes par les seules observations" », Revue d'histoire des mathématiques, 1, p. 201-233.

- GILAIN C. \& HOUZEL C. [1988], «Présentation », «Première partie » (Mathématiques), in P. Crépel \& C. Gilain [1988] (eds), p. 15-28.

- $\quad$ GRANGER G. G. [1956], La mathématique sociale du marquis de Condorcet, Paris, Odile Jacob, 1989.

- GRANGER G. G. [1971], «Condorcet», Dictionary of scientific biography, C. C. Gillipsie (ed.), New York, Charles Scribner's Sons, vol. III, p. 383-388.

- GROUCHY S. de [6 nivôse an VII (Dec. 26, 1798) \& 29 nivôse an VII (Jan. 18, 1799)], Lettres à A. A. Barbier, n. a. fr. 1390, f. 293-294, 291-292, in J. N. Rieucau [2005 b], p. 109-110, 112.

- GUILBAUD G. T. [1952], "Les théorie de l'intérêt général et le problème logique de l'agrégation », Economie appliquée, 5, n4, p. 501-584.

- GUILLAUME J. [1891], Procès-verbaux du Comité d'instruction publique de la Convention nationale, t. I (Oct. 15, 1792-July 2, 1793), Paris, Imprimerie Nationale.

- HAY L., « Nouvelles notes de critique génétique: la troisième dimension de la littérature » [1984], Texte, $\mathrm{n}^{\circ}$ 5-6, 1986-1987, p. 313-328.

- $\quad$ LA CHAPELLE (Abbé de) [1765], Institutions de géométrie, Paris, $3^{\text {rd }}$ ed. 
- LAGRANGE J. L. [1770-1773], «Mémoire sur l'utilité de la méthode de prendre le milieu entre les résultats de plusieurs observations », Euvres, Paris, Gauthier-Villars, 1867-1892, vol. II, p. 173-234.

- LAGRANGE J. L. [1773], «Sur la manière de former les tables des planètes par les seules observations », Euvres, Paris, Gauthier-Villars, 1867-1892, vol. VI, p. 507-627.

- $\quad$ LAGRAVE J. P. (de) \& BREGUET M. [1993], « Bibliographie », Lekton, vol. 3, n 1, spring, p. 273-340.

- LAPLACE P. S. [1774], "Mémoire sur la probabilité des causes par les événemens », Euvres, Paris, Gauthier-Villars, vol. VIII, 1891, p. 27-65.

- LOTY L. [1988], «Condorcet contre 1'optimisme: de la combinatoire historique au méliorisme politique », in P. Crépel \& C. Gilain [1988] (eds), 288-296.

- McLEAN I. \& HEWITT F. [1994], Condorcet - Foundations of Social Choice and Political Theory, Edward Elgar.

- O’CONNOR E. [July 25, 1845], Lettre à L. Barbier, n. a. fr. 1390, f. 307r.

- PARISOT S. A. [1810], « Préface », Traité du calcul conjectural ou l'art de raisonner sur les choses futures et inconnues, Paris, Bernard, Didot, Courcier, Béchet, p. VII-XXIV.

- PEARSON K. [1921-1933], The History of Statistics in the $17^{\text {th }}$ and $18^{\text {th }}$ centuries against the changing background of intellectual, scientific and religious thought, London, Charles Griffin \& Company limited, 1978.

- PETTY W. [1699], Several Essays in Political Arithmetic, London.

- RALLIER DES OURMES [1765], «Intérêt», Encyclopédie, vol. II, vol. 8, p. 819-823- the end p. 822-823 was written by d'Alembert.

- RIEUCAU J. N. [1998], «"Les entreprises où les hommes s'exposent à une perte, dans la vue d'un profit" Condorcet et l'héritage de d'Alembert », Revue économique, vol. 49, n5, p. 1365-1405.

- RIEUCAU J. N. [2003], «Les origines de la philosophie probabiliste de Condorcet - Une tentative d'interprétation », SVEC, Dec., p. 245-282.

- RIEUCAU J. N. [2005 a], «Condorcet- Mathématique sociale », Dictionnaire historique de la pensée sociologique, Paris, PUF, p. 116-118.

- RIEUCAU J. N. [2005 b], «Une correspondance inédite de Sophie de Grouchy et des éditeurs des Euvres dites Complètes de Condorcet », Recherches sur Diderot et sur l'Encyclopédie, vol. 39, p. 95-126.

- SIEYES E. J. [late June-early July 1793], « Du nouvel établissement public de l'instruction en France », Journal d’instruction sociale, $\mathrm{n}^{\circ}$ 3, p. 81-96; n4, p. 97-104; n5, p. 145-160; n6, p. 161-165.

- THUILLIER G. [1997], Le premier actuaire de France: Duvillard (1755-1832), Paris, Comité d'histoire de la Sécurité sociale, p. 465-486.

- $\quad$ TRINCANO D. G. [1781], Traité complet d'arithmétique, Paris, L. Cellot.

- VALADE B., « Condorcet» [1989], Encyclopcedia Universalis, Paris, 1990, vol. 6, p. 333-335. 
Appendix 1 : Tableau synoptique de la Mathématique sociale (1793)

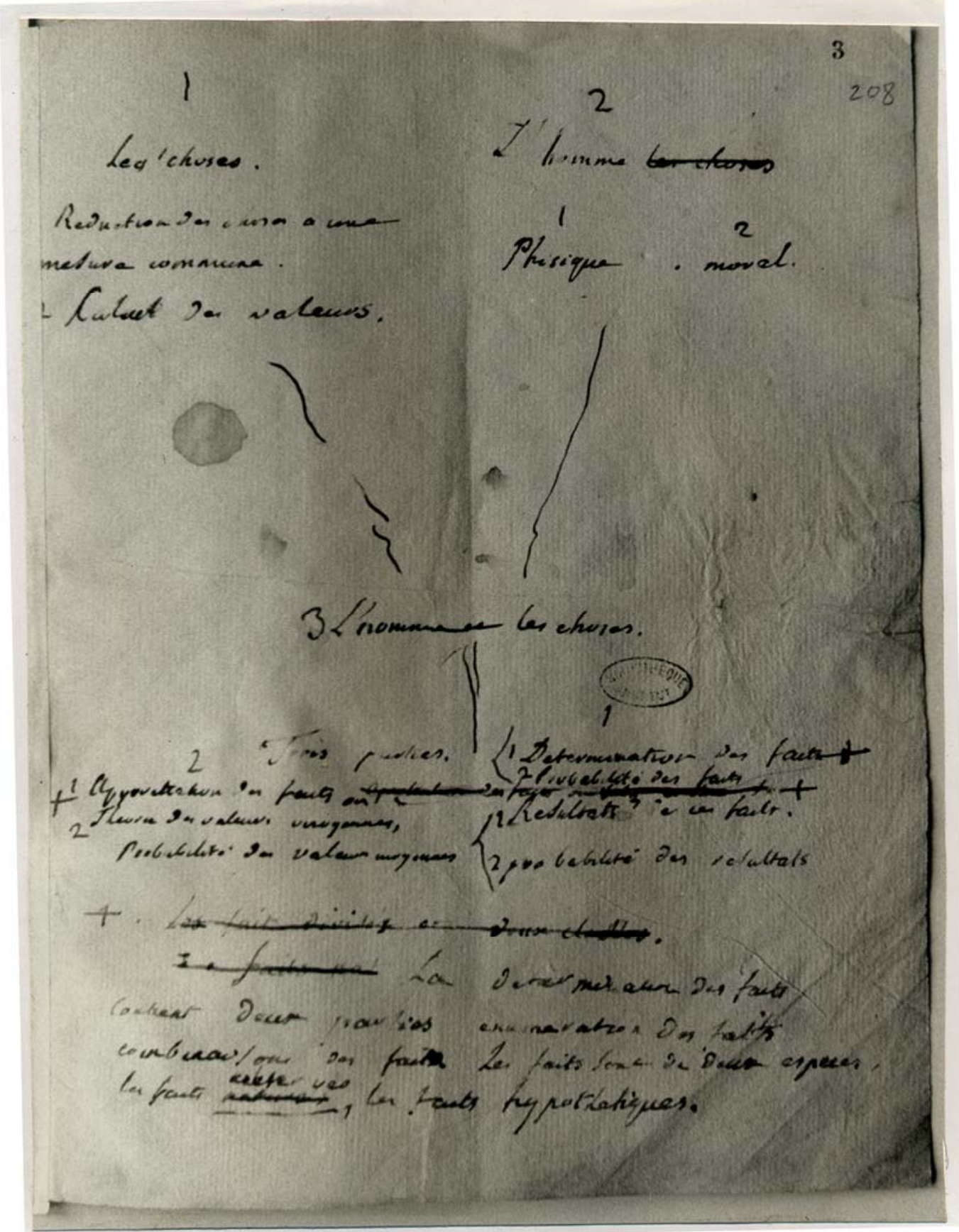

Autograph draft - Bibliothèque de l'Institut de France, MS 885 (II), f. $3=208$

Codicological description :

Laid paper, faint blue

Height : $201 \mathrm{~mm}$ ca

Width : $157 \mathrm{~mm}$ ca

Distance between chain lines (minimum-maximum) : 24-26 mm

Thickness (minimum-maximum) : 95-115 $\mu \mathrm{m}$

Countermark : « HENRY AINE » (name of the Papermaker)

The f. 3 (208) is folded in- $4^{\circ}$ (other half $=$ f. 1 (206)), with cut edges 


\section{Appendix 2 : Transcript of Appendix $1^{131}$}

1

Les choses.

1 Reduction des choses à une mesure commune. $2 *$ Calcul des valeurs.
2

\author{
L'homme Les choses
}

2

Phisique

moral
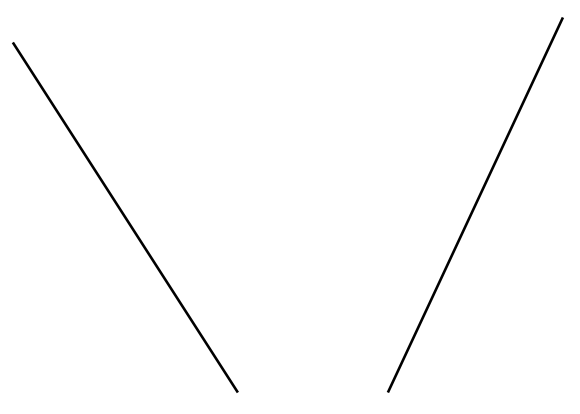

3 L'homme et les choses.

$\mid$

1

Trois parties.

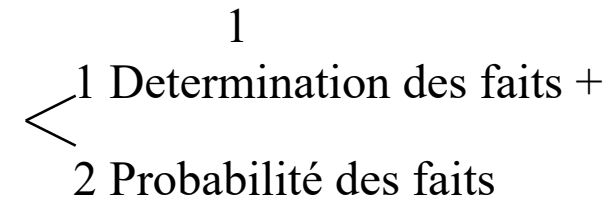

2

+ 1 Appretiation des faits ou Apretiation des faits ou faits evalués * Theorie des valeurs moyennes. $3+$

2 Probabilité des valeurs moyennes $<1$ Resultats de ces faits. $<_{2}$ Probabilité des resultats

+ Les faits divisés en deux classes.

I. Faits nat La determination des faits contient deux parties enumération des faits combinaisons des faits. Les faits sont de deux especes, les faits * naturels observés, les faits hypothetiques.

\footnotetext{
${ }^{131}$ Each cross that Condorcet noted on his manuscript, though it is roughly located, constitute probably a simple graphic sign that distinguishes the three parts of the method of the Social Mathematic («Determination des faits », «Appretiation des faits », " Resultats de ces faits ») as well as the content of the first of it.
} 
I.

L'HOMME.

1. L'homme individu.

2. Les opérations de l'esprit humain.
II.

\section{LES CHOSES.}

Réduction des choses à une mesure commune. Calculs des valeurs (1).

III.

L'HOMME ET LES CHOSES.

MÉTHODE DE LA SCIENCE.

I. DÉTERMINATION DES FAITS.

Énumération des faits.

1. faits observés.

2. faits hypothétiques.

Classification des faits (3).

Combinaisons des faits (2).

Probabilité des faits (4).
II. APPRÉCIATION DES FAITS.

Formation \& usages des valeurs moyennes (5).

Leur probabilité (4).

\section{RÉSULTATS DES FAITS.}

\section{Probabilité des résultats (4).}

\section{Théories préliminaires qui doivent précéder les applications}

(1). Théorie des grandeurs susceptibles d'accroissemens proportionnels.

(2). Théorie des Combinaisons.

(3). Méthode de déduire des faits individuels observés, soit les faits généraux qui en résultent, soit les loix générales qui y sont observées.

(4). Théorie générale des Probabilités.

(5). Théorie générale des Valeurs moyennes.

Appendix 3 : Restoration of « Tableau synoptique de la Mathématique sociale » 


\section{O}

DE la Mathématique Sociale.

I.

L'HOMME.

r. L'Homme individu.

2. Les opérations de l'efprit humain.
I I.

LES CHOSES.

à une mefure commune. Calcul des valeurs (I).

\section{I I.}

\section{L'Homme et les Choses.}

\section{Méthode de la Science.}

I.

Détermination des faits.

I. Faits obfervés. 2. Faits hypothétiques.
2.

Appréciation des faits.

Formation \& ufages des valeurs.

Moyens. 5 .

Leur probabilité (4).

I. Enumération des faits. 2. Claf-

fification. des faits.

(3) Combinaifons (2).

Probabilité des faits (4).

3.

Réfultat des faits.

Probabilité des réfultats (4).

Théories préliminaires qui doivent précéder les applications..

I. Théorie des grandeurs fufceptibles d'accroiffemens proportionnels.

2. Théorie des Combinaifons.

3. Méthode de déduire des faits individuels obfervés, foit les faits généraux qui en réfultent, foit les loix générales qui y font obfervées.

4. Théorie générale des Probabilités.

5. Théorie générale des Valeurs moyennes.

Appendix 4 : « Tableau synoptique de la Mathématique sociale »

Journal d'instruction sociale [22 juin 1793-6 juil. 1793]. Reprint : Paris, EDHIS, 1981, p. 119. 
254 TABLEAU GENERAL

$$
\text { O B J E T S }
$$

DE LA MATHEMATIQUE SOCIALE.

I.

I' मо $О \mathrm{M} \mathrm{x}$.

x. L'homme individu.

2. Les opérations de l'esprit humain.
I I.

L E 8 C H 0 \& $\mathrm{B}, 5$.

Réduction des choses a une mesure commune. Calcul des valeurs (1).

\section{I I.}

I'H OM M B R IES CHOS B 8 .

Methode de la science.

x.

Détermination des faits. Appréciation des faits.

1. Faits observés. 2. Faits valeurs.

Formation et usuges des

hypothétiques.

Moyens. 5.

s. Énumération des faits.

Leur probabilité (4).

2. Classification des faits.

(3) Combinaisons (2).

Probabilité des faits (4).

3.

Résultat des faits.

Probabilité des résultats (4).

Théories préliminaires qui doivent précéder les applications.

I. Théorie des grandeurs susceptibles d'acroissements proportionnels.

3. Théorie des combinaisons.

3. Méthode de déduire des faits individuels observés, soit les faits généraux qui en rúsultent, soit les lois générales qui y sont observées.

4. Théorie générale des probnbilités.

5. Théorie générale des valeurs moyennes.

Appendix 5 : « Tableau synoptique de la Mathématique sociale »

Euvres complètes de Condorcet [1804], S. de Grouchy, A. A. Barbier, P. G. Cabanis, D. J. Garat (ed.), Paris, Heinrichs, vol. 21, p. 254. 


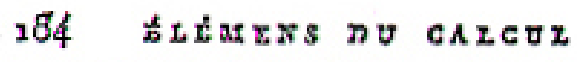

ner une théoric de la lune, d'aprìs laquelle on putt former des tables J'un usage sît. Mais la formation do ces mêmes tables, mais lemr application a la détermination des longitu: es, n'exigent que des connoissances êlémentaires.

Ce n'cst donc pas d'une science occulte, dont le sccret so:t renfermé entre quelques adeptes, qu'il s'ugit ici, c'estd'une science usuelle et commune; ; c'cst, à la fois, et d'aco célérer les progxès d'une théorio dont dépentent ceux des sciences les plus impor. tantes au bonheur public, et de répandre sur plusieurs parties de ces memes sciences, des lumieres d'uoe utilité générale et pratique.

OWETS DE LA MATHÉMATIQUE SOCHAE

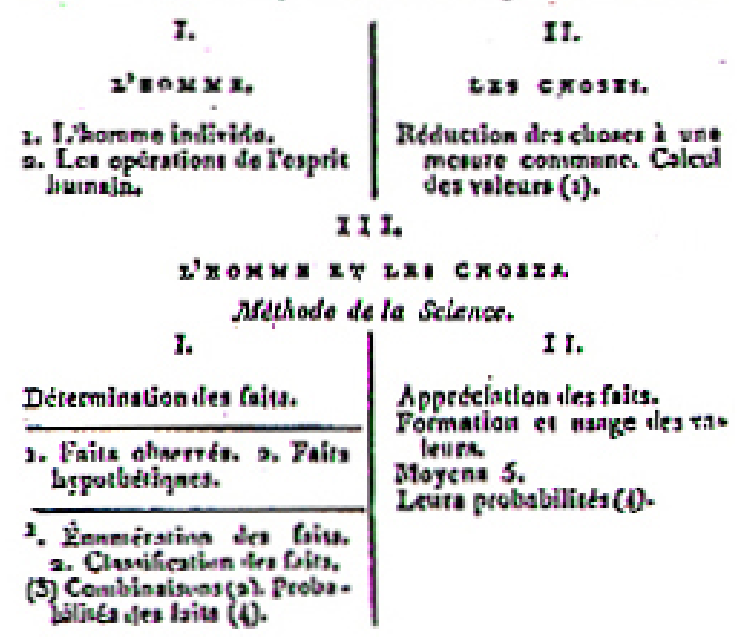

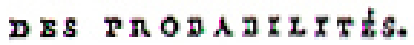
185

III.

MÉSULTAT DES FAITS.

MogantLITÉ DES NesULTat?.

Thíories prêliminaires qui doivent préctder les applications.

1. Théorie des grandeurs susceptibles d'accroisseinens proportionnels ;

2. Thé rie des coinbinaisons;

3. Métho:!e de dódure des faits individuels obscrvés, soit les faits généraux qui en résul!erit, soit les lois générales qui y sont observées ;

4.Théotic génñralo des probabilités;

5.Théoriegénéralecles valeurs moyennes.

Je vais $m$ intenant esquisser les divers objets d'économic socialo auxquels le calcul peut s'appliquer;

$2^{\circ}$. 1.'homme considéré comme individu.

On sait combien il est modifié jar la termpérature du cliınat, la nature dn sol, la nourriture, ?es babirndes génèrales de la vie; la nourriture, les pratiques préservatrices, les institutions sociales; et on peut deınnnder coumment ces causes diverses influent sur la durée de la vic, sur le rapport du noubre des individus de cliaque sexe, soit à la naissance, soit aux différens ages, sur celui du nombre des naissances, des maringes, des morts, avec le nombre des indiridus existans, sur celui des célibz-

Appendix 6 : « Tableau synoptique de la Mathématique sociale »

Élémens du calcul des probabilités et son application aux jeux de hasard, à la loterie et aux jugemens des hommes [1805], Fayolle (ed.), Paris, Royez, p. 184-185. 
DE LA SCIENCE, FTC.

OBJETS DE LA MATHËMATIQUE SOCIALE.

1.

$$
\text { L'HOMME. }
$$

1. L'homme individu.

2. Les opérations de l'esprit humain.
II.

LES CHOSES.

Réduction des choses à une mesure commune. Calcul des valeurs ( $\mathbf{I})$.

III.

\section{L'HOMME ET LES CHOSES.}

Méthode de la science.

I.

\section{Détermination des faits.}

1. Faits observés.

2. Faits hypothétiques.

צ. Énumération des faits.

2. Classification des faits.

Combinaisons (2).

Probabilité des faits (5).
Appréciation des faits (3). Formation et usages des valeurs. Moyennes (4). Leur probabilité (5).

3.

Résultat des faits.

Probabilité des résultats (5).

Théories préliminaires qui doivent précéder les applications.

(1) Théorie des grandeurs susceptibles d'accroissements proportionnels.

(2) Theorie des combinaisons.

(3) Méthode de déduire, des faits individuels observés, soit les faits généraux qui en résultent, soit les lois générales qui y sont observées.

(4) Théorie générale des valeurs moyennes.

(5) Théorie géuérale des prolabilités.

Appendix 7 : « Tableau synoptique de la Mathématique sociale »

Euvres de Condorcet [1847-1849], F. Arago \& E. O’Connor (ed). Reprint : Stuttgart-Bad Cannstatt, Friedrich Frommann Verlag, 1968, t. I, p. 551. 


\section{Objets de la mathématique sociale}

I

L'HOMME

I. L'homme individu

2. Les opérations de l'esprit humain
II

LES CHOSES

Réduction des choses

à une mesure commune.

Calcul des valeurs ${ }^{1}$

III

L'HOMME ET LES CHOSES

Méthode de la science

I

Détermination des faits

I. Faits observés

2. Faits hypothétiques

I. Énumération des faits

2. Classification des faits

Combinaisons

Probabilité des faits ${ }^{5}$
2

Appréciation des faits ${ }^{3}$

Formation et usages des valeurs Moyennes ${ }^{4}$

Leur probabilité 5

3 Résultat des faits
Probabilité des résultats

Théories préliminaires qui doivent précéder les applications Je vais maintenant esquisser les divers objets d'économie sociale, auxquels le calcul peut s'appliquer.

\section{L'HOMME CONSIDÉRÉ COMME INDIVIDU}

On sait combien il est modifié par la température du climat, la nature du sol, la nourriture, les habitudes générales de la vie, les pratiques préserva-

I. Théorie des grandeurs susceptibles d'accroissements proportionnels.

2. Théorie des combinaisons.

3. Méthode de déduire, des faits individuels observés, soit les faits généraux qui en résultent, soit les lois générales qui y sont observées.

4. Théorie générale des valeurs moyennes.

5. Théorie générale des probabilités.

Appendix 8 : «Tableau synoptique de la Mathématique sociale »

R. Rashed [1974], Condorcet, Mathématique et société, Paris, Hermann, p. 203. 
OBJETS DE LA MATHÉMATIQUE SOCIALE.

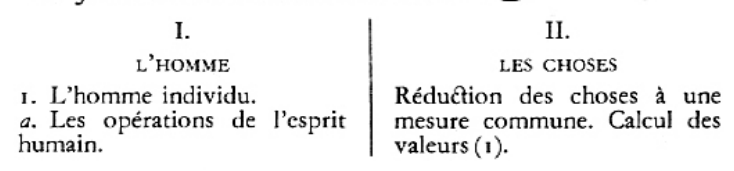

III.

\begin{tabular}{|c|c|}
\hline \multicolumn{2}{|c|}{$\begin{array}{l}\text { L'HOMME ET LES CHOSES } \\
\text { Méthade de la Science. }\end{array}$} \\
\hline Détermination des faits. & $\begin{array}{l}\text { II. } \\
\text { Appréciation des faits. }\end{array}$ \\
\hline $\begin{array}{l}\text { 1. Faits observés. 2. Faits } \\
\text { hypothétiques. }\end{array}$ & $\begin{array}{l}\text { Formation et usag } \\
\text { valeurs. } \\
\text { Moyens s. }\end{array}$ \\
\hline $\begin{array}{l}\text { 1. Énumération des faits. } \\
\text { 2. Classification des faits. } \\
\text { (3) Combinaisons (2). Proba- } \\
\text { blilités des faits (4). }\end{array}$ & \\
\hline
\end{tabular}

III .

RÉSULTAT DES FAITS probabilité des résultats

\section{Théories préliminaires} qui doivent précéder les applications

I. Théorie des grandeurs susceptibles d'accroissemens proportionnels :

2. Théorie des combinaisons ;

2. Méthode de déduire des faits individuels observés, soit les faits généraux qui en résultent, soit les lois générales qui y sont observées ;

4. Théorie générale des probabilités ;

5. Théorie générale des valeurs moyennes.

Je vais maintenant esquisser les divers objets d'économie sociale auxquels le calcul peut s'appliquer ;

$\mathrm{I}^{\circ}$ L'homme considéré comme individu.

On sait combien il est modifié par la température du climat, la nature du sol, la nourriture, les habitudes générales de la vie; la nourriture, les pratiques préservatrices, les institutions sociales; et on peut demander comment ces causes diverses influent sur la durée de la vie, sur le rapport du nombre des individus de chaque sexe, soit à la naissance, soit aux différens âges, sur celui du nombre des naissances, des mariages, des morts, avec le nombre des individus existans, sur celui des célibataires, des mariés, des veufs, soit de chaque sexe, soit des deux classes, avec ce même nombre total.

On verra ensuite de quelle manière ces causes influent sur la mortalité causée par les différentes classes de maladies.

Appendix 9 : «Tableau synoptique de la Mathématique sociale »

Condorcet. Sur les élections et autres textes [1986], O. de Bernon (ed.), Paris, Fayard, p. 606607. 


\section{OBJECTS OF SOCIAL MATHEMATICS ${ }^{4}$}

I

MAN

1. Man as an individual.

2. The operations of the human mind.
II

\section{THINGS}

The reduction of things to a general standard. The calculation of values. ${ }^{2}$

III

\section{MAN AND THINGS}

Scientific Method

Determination of the Facts.

1. Observed Facts.

2. Hypothetical Facts.

1. Enumeration of the Facts.

2. Classification of the Facts.

Combinations. ${ }^{e}$

Probability of the Facts. ${ }^{d}$
Appreciation of the Facts. ${ }^{b}$ Formation and use of values. Averages. ${ }^{c}$

Their probability. ${ }^{d}$

3

Results of the Facts.

Probability of the results. ${ }^{d}$

Preliminary theories which must precede applications.

\section{Theories involved}
a. The theory of quantities which can increase proportionally.
b. The method of deducing from individual observed facts either the general facts which result from them or the general laws which are observed.
c. The general theory of average values.
d. The general theory of probability.
e. The theory of combinations.

4. [The letters in brackets in this table refer to the theories listed at the end of the table.]

Appendix 10 : « Tableau synoptique de la Mathématique sociale »

Condorcet - Foundations of Social Choice and Political Theory [1994], I. McLean \& F. Hewitt (ed. \& translation), Edward Elgar, p. 99. 